\title{
D-8 Ülkeleri Arasında Parasal Birlik Mümkün Mü? Optimum Para Sahası Çerçevesinde İncelenmesi*
}

\author{
Is a Monetary Union Feasible for D-8 Countries? An Examination in The \\ Framework of The Optimum Currency Area
}

\section{Mervan SELÇUK' ${ }^{\oplus}$, Şakir GÖRMÜş² ${ }^{2}$}

\section{öz}

Parasal birlik, döviz kurlarında birliğin sağlanmasını, sermaye hareketlerinde tüm kısıtlamaların kaldırılmasını, üye ülkeler arasında konvertibilitenin gerçekleştirilmesini ifade etmektedir. Parasal birlik kavramı uzun zamandan beri tartışılsa da Avrupa Para Birliği'nin kurulması bu kavrama olan ilginin artmasına neden olmuştur. Avrupa ülkelerinin yaşadığı tecrübe ve üye ülkelerin bu konudaki bilgi birikiminin İslam ülkelerine aktarılması İslam ülkelerinin ekonomik istikrarı ve gelişimi açısından önemlidir. Çalışmamızda Gelişen Sekiz Ülke olarak ifade edilen D-8 ülkelerinin optimum para sahası olup olmadığını yani bir parasal birlik potansiyeli taşıyıp taşımadığı test edilmiştir. Bunun için 2000 ile 2020 yılları arasındaki çeyreklik döviz kuru, enflasyon, faiz ve dış ticaret verileri kullanılarak D-8 ülkelerinin yaşadığı şokların birbirine benzeyip benzemediği Vektör Hata Düzeltme modeli (VECM), EtkiTepki Fonksiyonu ve Varyans Ayrıştırma analizi vasıtasıyla incelenmiştir. Ülkelerin kendi aralarında başarılı ve sürdürülebilir bir parasal birlik kurmaları için ekonomik göstergelerinin birbirleriyle yakınlaşması veya benzerlik göstermesi gerekmektedir. VECM, Etki-Tepki Fonksiyonu ve Varyans Ayrıştırma analizi sonuçları beraber incelediğimizde; D-8 ülkelerinin tamamının optimum para sahası açısından uygun olmadığı fakat D-8 içerisinde bir alt grup olarak düşünülebilecek Türkiye, Nijerya, Mısır ve Malezya'nın diğer D-8 ülkelerine oranla, ilgili değişkenlerinde meydana gelen şokların benzer olduğu tespit edilmiştir. Bu ülkeler her ne kadar coğrafi olarak birbirine yakın olmasa da tesis edilecek parasal birlikte şokların simetrik olma kriteri açısından optimum para sahasının gerekliliklerini yerine getirebilecektir.

Anahtar Kelimeler: İslam Ülkeleri, Para Birliği, D-8, Avrupa Para Birliği, Optimum Para Sahası

Jel Sınıflaması: E43, F45, P44

DOI: 10.26650/JEPR1002262

\author{
*Bu çalışma, Dr. Mervan Selçuk'un Prof. Dr. Şakir \\ Görmüș danışmanlığında yazdığı doktora \\ tezinden elde edilmiştir (Tez No: 676222). \\ 'Sakarya Üniversitesi, İslam Ekonomisi ve \\ Finansı \\ Uygulama ve Araştırma Merkezi, Sakarya, \\ Türkiye \\ 2Sakarya Üniversitesi, Siyasal Bilgiler Fakültesi, \\ Maliye Bölümü, Sakarya, Türkiye \\ ORCID: M.S. 0000-0001-8384-373X \\ Ş.G. 0000-0002-1857-8682

\section{Sorumlu yazar/Corresponding author: Mervan SELÇUK, \\ Sakarya Üniversitesi, İslam Ekonomisi ve Finansı Uygulama ve Araştırma Merkezi, Sakarya, Türkiye \\ E-posta/E-mail: \\ mervanselcuk@sakarya.edu.tr}

Başvuru/Submitted: 29.09.2021

Revizyon Talebi/Revision Requested: 03.11.2021

Son Revizyon/Last Revision Received: 17.11.2021

Kabul/Accepted: 22.11.2021

Atıf/Citation: Selcuk, M., \& Gormus, S. (2022)

D-8 ülkeleri arasında parasal birlik mümkün mü? Optimum para sahası çerçevesinde incelenmesi. Iktisat Politikası Araștırmaları Dergisi - Journal of Economic Policy Researches, 9(1), 75-101.

https://doi.org/10.26650/JEPR1002262 


\begin{abstract}
A monetary union means ensuring unity in exchange rates, eliminating all restrictions on capital movements, and realizing convertibility among member countries. Although this concept is not new, the establishment of the European Monetary Union has led to renewed interests. Applying the European member countries' experience and knowledge on this subject is crucial for the economic stability and development of Islamic countries. Using the quarterly data of the exchange rate, inflation, interest rate, and trade during 2000-2020, our study tests whether the D-8 is an optimum currency area. Based on the results of the vector error correction model, the impulse response function, and the variance decomposition, it has been determined that the D-8 as a whole is not an optimum currency area. However, Turkey, Nigeria, Egypt, and Malaysia, considered as a subgroup within the D-8, experience relatively similar shocks to their exchange rates, inflation, interest rates, and trade, as compared with the rest of the D-8. Although these countries are geographically fragmented and distant, their theoretical monetary union would be an optimum currency area in terms of the symmetry of their shocks.
\end{abstract}

Keywords: Islamic Countries, Common Currency, D-8, The European Monetary Union, Optimum Currency Area Jel Classification: E43, F45, P44

\title{
EXTENDED ABSTRACT
}

Globalization movements and exchange rate fluctuations deeply affect fragile economies and pose risks. Countries have developed various policies to eliminate this exchange rate risk. A monetary union, which is formed by a group of countries, is a crucial tool against the exchange rate risk. This has many benefits, such as the reduction of transaction costs, encouragement of international trade, elimination of exchange rate uncertainty, reduction of information costs, prevention of speculative capital movements, and creation of price transparency. These further benefit consumers and producers. A monetary union also provides microeconomic efficiency because it facilitates price comparison. Therefore, the prices of the member states of the union are expected to converge. Moreover, a monetary union will inevitably create some costs and disadvantages for the member countries. These disadvantages include a loss of national monetary policy independence, imbalances between member countries, problems caused by demand changes, inability to meet unemploymentinflation targets, and deprivation of national seigniorage income.

The Optimum Currency Area theory provides two sets of measures that would maximize economic efficiency for an entire region to enable the use of a single currency. The first one is the mitigation of exposure to asymmetric shocks through the similarity of economic structures, openness of trade, and low degree of specialization. The second group is easing adjustment to asymmetric shocks through preference homogeneity, factor mobility, and transfer payments. With this in consideration, the Maastricht criteria are based on economic indicators that European Union member countries must fulfill to get into the European currency area and that they must ensure to maintain once got in the union. To establish a successful and sustainable monetary union, the economic indicators of the countries must 
converge and resemble each other. These indicators are inflation rates, budget deficit rates, public debt, and interest rates.

Although the concept of a monetary union is nothing new, the establishment of the European Monetary Union has led to renewed interest. Applying the European member states' experience and knowledge on this subject is an crucial step for the economic stability and development of Islamic countries. Using quarterly data on the exchange rate, inflation, interest rate, and trade between 2000 and 2020, our study tests whether the D-8 is an optimum currency area. Based on the results of the vector error correction model, the impulse-response function, and the variance decomposition, it has been determined that the D-8 as a whole is not optimum currency area. However, Turkey, Nigeria, Egypt, and Malaysia, which can be considered as a subgroup within the D-8, experience relatively similar shocks to their exchange rates, inflation, interest rates, and trade, as compared with the rest of the D- 8 countries. Therefore, although these countries are geographically fragmented and distant, their theoretical monetary union would be an optimum money field in terms of the symmetry of their shocks.

To adopt a new common currency among D-8 countries, they have to provide economic, political, and financial integration consistent with the relevant policies and meet specific conditions designed to ensure economic convergence. It should not be forgotten that longterm preparation, which took almost 10 years, laid the groundwork for a successful European Monetary Union. The example set by the European Monetary Union should serve as the template for D-8's goal of a monetary union consisting of Islamic countries. 


\section{Giriş}

Küreselleşme hareketleri ile döviz kurunda yaşanan istikrarsızlıklar özellikle kırılgan ekonomileri derinden etkilemekte ve risk oluşturmaktadır. Ülkeler bu döviz kuru riskini ortadan kaldırmak için çeşitli politikalar geliştirmişlerdir. İktisadi ilişkilerin çok yoğun olduğu ülkeler ulusal paralarını sabit kurlarla birbirlerine endeksleyerek ortak bir para kullanması ve ortak para politikasını düzenleyecek bir merkez bankası tesis etmeleri parasal birlik olarak tanımlanmakta ve döviz kuru riskine karşı önemli bir araç olarak kullanılmaktadır. Bunun yanında iktisadi ilişkileri güçlü olan bir grup ülkenin paralarını sabit kurlarla birbirlerine bağlaması da para sahası olarak adlandırılmaktadır. Para sahası ve para birliği arasındaki temel fark ise; para sahasında paralar kendi fonksiyonlarını korurken, parasal birlikte ulusal paraların fonksiyonları terk edilerek ortak bir paraya ve otoriteye devredilir (Varan, 2010). Devletler, parasal birliği kabul etmesi halinde parasal konulardaki politika bağımsızlıklarından feragat ederek bu konulardaki yetkilerini devletler üstü bir kuruma yani birliğin oluşturduğu merkez bankasına devreder (Evlimoğlu, 2005).

Parasal birliğin işlem maliyetlerini azaltması, uluslararası ticareti teşvik etmesi, döviz kuru belirsizliğini gidermesi, spekülatif sermaye hareketlerinin önlenmesi ve fiyat istikranın sağlanması gibi pek çok faydasının yanında rezerv paraların sahip olduğu senyoraj hakkının elde edilmesi, uluslararası alanda ekonomik bir güç bloğunun oluşturulması, tüketici ve üreticiler için enformasyon maliyetini azaltması gibi faydaları bulunmaktadır. Parasal birlik fiyat karşılaştırmasını kolaylaştırdığından mikro-ekonomik etkinliği de sağlayacaktır. Fiyat karşılaştırması şeffaflığı sağlayacak ve birliğe üye ülke fiyatları yakınsayacaktır (Yücememiş, 2004).

Parasal birliğin üye ülkelere sağladığı bu faydaların yanında bazı maliyetlere de neden olması kaçınılmazdır. Bu maliyetler ulusal para politikası bağımsızlığından feragat, üye ülkeler arasındaki dengesizlikler, talep değişmelerine bağlı ortaya çıkan problemler, işsizlikenflasyon hedeflerinin tutturulamaması ve ulusal senyoraj gelirinden mahrum kalınması olarak say1labilir (Varan, 2010).

Parasal birlik ve Optimum Para Sahası (OPS) literatürü incelendiğinde; parasal birlik ile ilgili yapılan çalışmaların büyük bir bölümü başta Avrupa Para Birliği (APB) ve Doğu Asya ülkeleri olmak üzere potansiyel ve mevcut parasal birliklerin etkinliğini ve sürdürülebilirliğini konu edinmektedir. İslam ülkeleri, İslam İşbirliği Teşkilatı ve D-8 gibi farklı ülke gruplarının parasal birlik çerçevesinde inceleyen çalışmaların kısıtlılığ kılmaktadır.

Çalışmamızın amacı İslam ülkeleri arasında bir parasal birliğin kurulup kurulamayacağını OPS teorisi çerçevesinde incelemektir. Bu ülkelerin OPS oluşturup oluşturmayacağının 
ekonometrik yöntemlerle tespit edilmesi İslam ülkeleri arasındaki ekonomik iş birliğinin arttırılarak ekonomik istikrarın sağlanması açısından önemlidir. İslam İşbirliği Teşkilatı (İIT)'na üye bütün ülkelerden sağlıklı veri elde edilememesi nedeniyle örneklem olarak Gelişen Sekiz Ülke (D-8) seçilmiş ve yaşadıkları şokların benzer olup olmadığı test edilmiştir.

Parasal birlik kavramı, OPS teorisinin gelişimi ve dünyadaki örnekleri çalışmamızın ikinci bölümünde yer almaktadır. Üçüncü bölümde OPS ve parasal birlikle ilgili literatür ve ekonometrik çalışmalar incelenmiştir. Çalışmanın dördüncü bölümünde İslam Ülkeleri arasındaki parasal birlik konu edinilmiş ve beşinci bölümde D-8 ülkeleri OPS kapsamında değerlendirilmiştir. Tartışma ve sonuç, çalışmanın son bölümü oluşturmaktadır.

\section{Parasal birlik}

Parasal birlik fikri siyasi, mali, kurumsal ve diğer ekonomik entegrasyon biçimleri göz ardı edilerek oluşturulamaz (Arif ve Shabbir, 2019). Ülkeler, uygun bir para birliği oluşturmak için sosyo-ekonomik ve politik yapılarını çeşitlendirmek zorundadır. Ülkelerin kendi aralarında başarılı ve sürdürülebilir bir parasal birlik kurmaları için bazı ekonomik göstergelerinin birbirleriyle yakınlaşması ve benzerlik göstermesi gerekmektedir. Parasal birliğin başarılı olabilmesi için öncelikli olarak enflasyon oranlarının, bütçe açığı oranlarının, kamu borçlarının, faiz oranlarının birbirine yakınsaması ve bunlara ek olarak faktör hareketlerinin serbest olmasi gerekmektedir (Varan, 2010).

Parasal birliğin teorik altyapısını OPS teorisi açıklamaktadır. 1999 yılında Nobel Ekonomi Ödülü'nü kazanan Robert Mundell'in 1961 yılında yayımladığı “Optimum Kur Alanları Teorisi” adlı çalışmasıyla bu konu gündeme gelmiştir. OPS teorisi, belirli bir grup ülkenin ulusal paralarını birbirlerine karşı sabitlerken, bu grup dışı ülkelere karşı dalgalı bir kur rejimi belirlenmesi olarak ifade edilebilir (Varan, 2010).

OPS teorisi; ulusal paraların belli bir paraya sabitlendiği optimal bir coğrafi alanı belirlemektedir. Para birliği teorisi ise bu noktadan hareketle daha ileri bir aşamayı ifade ederek, ortak para anlaşmasına katılan ülkelerin ortak para ve tek merkez bankasına geçmeleri süreciyle ilgilenir. OPS çerçevesinde Mundell (1961) faktör hareketliliğine, McKinnon (1963) dişa açıklığa, Kenen (1969) ürün çeşitliliğine, Ingram (1962) finansal entegrasyona, Fleming (1971) ise fiyat istikrarına odaklanmıştır. Bunun yanında mali entegrasyon, politik entegrasyon ve şokların benzerliği parasal birliği etkileyen faktörler olarak literatürde açıklanmıştır (Tavlas, 2009; Yılmaz, 2014).

OPS, parasal birliğin faydalarının, maliyetlerine karşı avantajlı olduğu durumlarda ülke gruplarının rekabet avantajı elde etmek ve ekonomik açıdan ülkeler arası entegrasyonu 
sağlamak amacıyla tercih edilen bir araçtır. OPS'nin tesis edilebilmesi için ortak para kullanacak ülkelerin belirli özelliklere sahip olmaları gerekmektedir (Şimşek, 2005). Bu özellikler şu şekilde sıralanabilir:

\section{Parasal birliğe üye olacak ülkelerin ekonomik yapılarının benzeşmesi}

Benzer ekonomik şoklara maruz kalmaları

Makro ekonomik göstergelerin birliğin oluşum sürecinde veya sonradan birliğe dahil olacak ülkeler için yakınsaması

$>$ Ürün çeşitliliğine sahip olmaları

> Dışa açıklık, mekansal yakınlık ve üye ülkelerin birbirleriyle ticareti gibi pek çok faktörün aynı anda gerçekleştirilmesi gerektiği açıktır.

Dünyadaki parasal birlik tecrübelerine baktığımızda; Latin Para Birliği (LPB) ve İskandinav Para Birliği (İPB) parasal birliklerin öncülerinden olmuştur (Bordo ve Jonung, 2003). Devam eden süreçte Belçika-Lüksemburg Ekonomik Birliği (BLEB), CFA Frank Sahası, Doğu Karayip Para Birliği (DKPB) ve Ortak Para Alanı (OPA) olmak üzere uluslararası para birlikleri tesis edilmiştir. Ayrıca günümüzde bu birliklerden bazıları faaliyetlerini sürdürmektedir (Yılmaz, 2014). 19. yüzyılda, sömürgeci güçlerin para kurulları, özellikle İngiliz kolonilerinde ortak bir parasal düzenlemeyi sağlamak için ortaya çıkmıştır. Sömürge gücünün ihraç ettiği paralar, belirli bir rezerve karşılık olarak piyasaya sürülerek para kurulları oluşturulmuştur. Para kurulları, sömürgeci gücün, banknot ve madeni paralar aracılığıyla piyasayı kontrol altında tutmasına imkân sağlıyordu. Ayrıca bu para kurulu, koloni ile anavatan arasındaki parasal birliği, daha doğrusu bir döviz kurunu temsil ediyordu (Bordo ve Jonung, 2003). Çoğu koloni 1950’ler ve 1960'larda bağımsızlık kazandıktan sonra kendi merkez bankalarını kurmuş, bunun akabinde para kurullarını kaldırmışlardı. Fakat DKPB ve CFA Frank Sahası gibi devam eden para birlikleri de bulunmaktadir (Bordo ve Jonung, 2003).

Buna karşın parasal birliklerin başarısız olmasının veya dağılmasının pek çok nedeni bulunmaktadır. Bu nedenlerin başında; savaşlar neticesinde ulusların bağımsızlığını elde etmesi, siyasi istikrarsızlıklar ve birlik üyelerinden bazılarının diğer para birliğine üye olan ülkelere göre kendi çıkarını daha fazla düşünerek hareket etmesi gelmektedir. Fakat şurası da unutulmamalıdır ki üye ülkelerin ekonomik, politik ve askeri anlamda aynı seviyede olduğu parasal birliklerde koordinasyon sorunu ortaya çıkacağı düşünülmektedir. Güç dengesinin birkaç ülkede olduğu parasal birliklerde karar alma ve koordinasyon daha kolay gerçekleşmektedir. Avrupa Para Birliği (APB)'de Almanya'nın konumu buna örnek olarak verilebilir (Yücememiş, 2004). 
II. Dünya Savaşı'ndan sonra yaşanan acıların tekrarlanmaması düşüncesiyle siyasi ve ekonomik birliğin tesis edilmesi için adımlar atılmıştır. Bu düşünceyle ilk olarak 1951 yılında Avrupa Kömür ve Çelik Topluluğu kurulmuştur. Gümrük Birliği ve Ortak Pazar gerçekleştirilmiş, bunun akabinde parasal birlik kurularak ekonomik entegrasyon sağlanmıştır. Döviz kurlarında istikrarın sağlanması, ekonomik refahın arttırılması ve Avrupa'nın tam anlamıyla bütünleşmesi amacıyla APB'nin düşüncesinin temelleri 1960'lı yıllara dayanmaktadır (Yücememiş, 2004).

APB anlaşması olarak da bilinen Maastricht Antlaşması 1992 yılında imzalanmış ve 1993 yılında yürürlüğe girmiştir. Üç aşamalı bir süreç sonucunda fiili olarak parasal birliğe geçilmesi ve ortak merkez bankasının faaliyetlerine başlaması kararlaştırılmıştır. Fakat bu hedeflere ulaşılabilmesi için süreç içerisinde birliğe dahil olan ülkelerin aşağıda belirlenen yakınsama kriterlerini başarıyla yerine getirmesi gerekmekteydi (Kava, 2005; Yılmaz, 2014).

Döviz Kuru İstikrarı: Ülkelerin döviz kuru istikrarını sağlaması gerekmekte ve Avrupa Döviz Kuru Mekanizması'nda en az 2 yıl süre bulunmaları gerekmektedir.

Bütçe Açığı: Ülkelerin bütçe açıkları GSYİH'sının \%3’ünü geçmemelidir.

Kamu Borcu: Topluluk ülkelerinin kamu borcu GSYİH'sının \%60’ından fazla olmamalidir.

Faiz Oranı: Ülkelerin uzun vadeli faiz oranları, en düşük enflasyon oranına sahip üç ülkenin uzun vadeli faiz oranı ortalamasına göre \%2'den daha fazla olmaması gerekmektedir.

> Enflasyon: Ülkelerin enflasyon oranları, en düşük enflasyona sahip üç ülkenin yıllık enflasyon oranı ortalamasına göre $\% 1,5$ 'den daha fazla olmaması gerekmektedir.

Ayrıca APB'ne katılacak ülkeler birliğe dahil olmadan önceki 2 yıl boyunca paralarını devalüe etmemiş olması gerekmektedir. Bunun nedeni üye ülkelerin manipüle edilmiş bir para yapısıyla birliğe dahil olup diğer ülkelerin aleyhine bir avantaj elde edilmesini önlemektir (De Grauwe, 2017).

Topluluk üyelerinin para politikasını tek bir çatı altında organize edilmesi için 1 Haziran 1998 yılında Avrupa Merkez Bankası (AMB) kurulmuştur. Parasal birliğin sürdürülebilir bir şekilde işletilebilmesi için AMB'na düşen görevler bulunmaktadır. Bu görevler şu şekilde siralanabilir (Varan, 2010):

APB için ortak para politikası geliştirmek ve uygulamak.

Birliğin belirlenen doğrultuda fiyat istikrarını korumak, ekonomi politikalarını desteklemek ve rekabetçi piyasalara karşı etkinlik göstermek. 
Ödeme sistemlerinin işlemesini sağlamak.

Üyelerin AMB'na yatırdığı döviz rezervlerini idare etmek.

Birliğin döviz kuru rejimine uygun işlemler yapmak.

Avrupa Merkez Bankası Sistemini denetlemek, koordinasyonunu sağlamak ve bu doğrultuda belirlenen politikaları uygulamak.

Diğer merkez bankalarında olduğu gibi AMB'nın en temel görevi fiyat istikrarını sağlamaktır. Bundan dolayı Euro bölgesindeki para arzının kontrol edilmesi, faiz oranlarının belirlenmesi ve kredi hacminin kontrolü görevleri bu açıdan ön plana çıkmaktadır (Varan, 2010).

\section{Literatür}

İlgili ülkelerin OPS olup olmadığını test etmek için OPS teorisinin farklı yönleri dikkate alınmaktadır. Bu yönlerden biri de potansiyel OPS üyelerinin yaşadıkları şokların benzer olup olmadığıdır. Ülkelerin yaşadıkları şokların simetrik olması halinde aynı tip politikaların ekonomik kayıpları en aza indirebileceğini ve toplam faydayı arttıracağını, asimetrik şoklar yaşayan ülkelerde ise ortak bir para politikasıyla toplam faydanın yeterince sağlanamayacağı belirtilmektedir. Ayrıca ülkelerin ekonomik açıdan birbirine uyum hızı farklılık gösteriyorsa benzer ekonomik politikalar şokların oluşturduğu maliyetleri en aza indirmeye yardımcı olmamaktadır (Samsar, 2003).

Literatürde kullanılan yöntemler incelendiğinde; OPS'yi test eden farklı yöntemlerin bulunmasına karşın VAR/VECM yönteminin sıklıkla tercih edildiği tespit edilmiştir. Özellikle etki-tepki fonksiyonu ve varyans ayrıştırması ile incelenen ülkelerin yaşadıkları şokların simetrik olup olmadığını test etme konusunda VAR/VECM yöntemi ön plana çıkmaktadır. Bu konu ile ilgili yapılan çalışmaları aşağıdaki gibi örneklendirebilir.

Doğu Asya'da 1997 yılında ortaya çıkan kriz, bölge ülkelerinde döviz kuru istikrarını sağlamak için OPS politikalarına olan ilgiyi artırmıştır. Doğu Asya ekonomilerinin bölgedeki döviz kuru istikrarını ve kredibilitesini potansiyel olarak artırabilecek alternatif bir döviz kuru düzenlemesine olanak sağlayan parasal birlik ile ilgili çok sayıda akademik çalışmalarla bu sorunun çözümü için alternatifler olup olmadığı test edilmiş, özellikle Doğu Asya ekonomilerinin makroekonomik göstergelerindeki değişimlerin simetrik olup olmadığ1, OPS teorisi çerçevesinde incelenmiştir (Lee \& Azali, 2010, 2012; Mishra \& Sharma, 2010; Nguyen, 2010).

Lee ve Azali (2010) çalışmasında GMM yöntemini kullanarak Doğu Asya ekonomileri için ticaret, finans, uzmanlaşma ve iş döngüsü arasındaki ilişkiyi incelemektedir. Elde edilen 
sonuçlara göre; ticaret, finans ve sektörel uzmanlaşmanın ülkeler arasındaki ortak şokların boyutu üzerinde ortak bir etkiye sahip olduğuna dair bulgulara dayanarak, Doğu Asya ülkelerinin bölgesel bir para birliği tesis edebileceğini ortaya koymaktadır. Aynı yazarlar bir başka çalışmada yine Doğu Asya ekonomilerinin döviz kuru istikrarını ve kredibilitesini potansiyel olarak artırabilecek alternatif bir parasal birliğin mümkün olup olmadığını Avrupa ve Kuzey Amerika ülkeleriyle karşılaştırmalı olarak incelemiştir. 1970 yılı ile 2000 yılı arasındaki dönemi Doğu Asya ülkeleri için incelendiğinde, bölgesel faktör büyüklüğünün Avrupa Birliği ve Doğu Asya için aşağı yukarı aynı olduğu görülmektedir. Tekil ülke etkilerinin azalan payı ve artan bölgesel işbirlikleri neticesinde Doğu Asya'nın para birliği için giderek daha elverişli hale geldiği tespit edilmiştir (Lee ve Azali, 2012).

Mishra ve Sharma (2010) hazırladıkları çalışmada sekiz Doğu Asya ülkesinde döviz kurlarında ortaya çıkan dalgalanmaların birlikte hareketini OPS potansiyelini test etmek amacıyla incelemiştir. Elde edilen sonuçlara göre Doğu Asya'da OPS'nin tesis edilmesini destekleyen kanıtlar bulunmuştur. Bunun yanında, bölge ülkelerinin yaşanan şoklara uyum sağladıkları oranla daha az ekonomik entegrasyonun gerekli olduğunu göstermektedir. Buna karşın Nguyen (2010)'in çalışmasında Doğu Asya ülkelerinin Avrupa ülkeleri kadar bir parasal birlik altyapısına sahip olmadığı görülmüştür. Fakat Doğu Asya'da devam eden ekonomik entegrasyon çalışmaları göz önüne alındığında, bu bölgede parasal birlik tesis edilmesi bölge ülkelerinin ekonomik istikrarına katkı sağlayacağını belirtmiştir.

Couharde ve diğerleri (2013) yaptıkları çalışmada CFA ülkelerinin, OPS kriterlerinin çoğunu yerine getirememelerine rağmen neden başarılı bir şekilde para birliğini sürdürdüklerini açıklamayı amaçlamaktadır. Ülke bazlı elde edilen bulgular, ülkeler arası farklılıkların hem uzmanlaşma modellerinde hem de heterojenliğe atfedilebileceğini göstermektedir. Bu heterojenlik, genellikle CFA bölgesinin optimalliğini reddetmek için ileri sürülse de reel döviz kurlarının ayarlanmasında bir fren görevi görmediğini ortaya koymaktadir.

Harvey ve Cushing (2015) hazırladıkları çalışmada Batı Afrika Para Bölgesi’nin yapısal şokların doğrusal bağımlılığını VAR modeli kullanarak parasal birlik olup olmadığını test etmektedir. Elde edilen sonuçlara göre OPS'den beklenen şokların benzer olması Batı Afrika Para Bölgesi ülkeleri için geçerli değildir ve ülkelerin yaşadıkları şoklar benzeşmemektedir. Numa (2011), MERCOSUR (Arjantin, Brezilya, Paraguay ve Uruguay arasında bir ticaret anlaşması) bünyesinde bir para birliğinin fizibilitesini uzun vadeli bir bakış açısıyla OLS, VAR ve Granger nedenselliğiyle analiz etmektedir. Elde edilen sonuçlar, ülkelerin yeterli düzeyde entegrasyon sağlayamadıkları ve ülke ekonomilerinde dalgalanmalar nedeniyle bu dört ülkenin para birliğine hazır olmadığını göstermektedir. Hafner ve Kampe (2018) hazırladıkları çalışmada 20 Latin Amerika ülkesini 1990 yılı ile 2014 yılı arasında 
inceleyerek bir para birliğinin ve onun mevcut başlıca bölgesel ticaret anlaşmalarındaki potansiyelini değerlendirmek için Latin Amerika'da OPS teorisini test etmektedir. Elde edilen sonuçlara göre, Latin Amerika ülkelerinin asimetrik şoklara maruz kalması ve makroekonomik krizlere yanıt olarak uyum sağlama kapasiteleri sınırlı olması nedeniyle OPS olmaktan uzak olduğu tespit edilmiştir.

Rafiq (2011), Körfez İşbirliği Konseyi (KİK)'deki büyüme oranlarına odaklanarak, KİK için tesis edilecek bir parasal birliğin optimalliğini araştırmaktadır. Elde edilen sonuçlar, KİK genelinde büyüme oranları senkronizasyonunun, özellikle 1990'ların başından beri konjontür dalgalanmaları içerisinde önemli ölçüde arttığını göstermektedir.

Kazerooni ve Razzaghi (2014) yapmış oldukları çalışmada D-8 ülkeleri arasında oluşturulacak bir parasal birliğin fizibilitesini; GDP, enflasyon ve reel döviz kuru şoklarının simetrisini dikkate alarak yapısal VAR modeli aracılığıyla incelemiştir. Elde ettikleri sonuçlara göre; Malezya, Nijerya, Türkiye ve Pakistan'daki yapısal şokların simetrik olduğu tespit edilmiştir. Ayrıca bu ülkelerin etki-tepki fonksiyonu analizi sonucundaki dengeye ulaşma dönemlerinin aynı olduğu sonucuna ulaşılmıştır. Varyans ayrıştırma sonuçları ise Malezya, Nijerya, Türkiye ve Pakistan'da GDP, reel döviz kuru ve enflasyondaki değişimin aynı olduğunu ortaya koymuştur. Sonuç olarak D-8 ülkeleri arasında yer alan Türkiye, Pakistan, Nijerya ve Malezya'nın oluşturacağı altgrup arasında parasal birliğin tesis edilmesinin OPS çerçevesinde mümkün olduğu ortaya koyulmuştur.

\section{4. İslam ülkeleri arasında para birliği}

İslam İşbirliği Teşkilatı (İIT)’ye üye olan İslam ülkelerinin ekonomik yapılarına baktığımızda, üye ülkelerin ekonomik göstergelerinin birbirine benzemesi veya finansal açıdan yakınsaması mümkün değildir. Çünkü kimi ülkeler yeraltı kaynaklarından yoksun ve çok fakirken kimileri petrol ve türevlerinin getirmiş olduğu yüksek refah düzeyine sahiptirler. $\mathrm{Bu}$ açıdan parasal birliğin doğrudan İİT'ye üye bütün ülkeleri kapsayacak şekilde tasarlanması modelin anlamlı bir sonuca ulaşmasına engel olacaktır. Bundan dolayı parasal birliğe dahil edilecek ülkelerin mali ve finansal yapıları, makro ekonomik göstergeleri ve piyasa düzeni birbirine benzemesi gerekmektedir. Bu ülkeler arasından Gelişen Sekiz'i (D8) oluşturan Bangladeş, Mısır, Endonezya, Malezya İran, Nijerya, Pakistan ve Türkiye’nin ortaya koyduğu ortak pazar ve parasal birlik misyonu, çalışmamızda örneklem olarak D-8 ülkelerinin seçilmesini sağlamıştır.

1997 yılında İIT içerisindeki sekiz en büyük ekonomiye sahip ülkelerden oluşan D-8'de esnek kur rejiminin uygulandığ 1 ve döviz kuru riskinden korunma enstrüman ve bilgisinin eksik olduğu aynı zamanda döviz kuru riskinin doğrudan uluslararası ticareti, enflasyonu ve faiz oranlarını etkilediği görülmektedir. Örneğin, Türkiye'nin petrol ve doğalgaz konusunda 
dışa bağımlı olması ve bu ürünlerin ticareti dolar ile gerçekleştirilmesi neticesinde döviz kurundaki artış, ülke ekonomisine çok büyük zararlar vermekte ve enflasyon hedeflerinin tutturulamamasına sebep olmaktadır. Bu durum diğer D-8 üye ülkeleri için de geçerlidir. D-8 üyeleri arasında ticaret hacminin arttırılması ve döviz kuru riskinin oluşturduğu olumsuzlukların bertaraf edilmesi açısından parasal birlik alternatif bir çözüm sunabilir.

D-8 Ekonomik İşbirliği Teşkilatı, 54. Türkiye Hükümeti Başbakanı Prof. Dr. Necmettin Erbakan öncülüğünde 1997 yılında İ̇T içerisinde teknolojik, ekonomik, nüfus ve stratejik konum açısından önemli bir yere sahip olan sekiz İslam ülkesinin (Bangladeş, Endonezya, İran, Malezya, Mısır, Nijerya, Pakistan ve Türkiye) sosyal, ekonomik, kültürel ve güvenlik alanlarında iş birliğini hedefleyerek kurulmuştur (Çelik, 2018). D-8'in kuruluş ilkeleri ve kapsadığı coğrafi alan baktığımızda, bu birliğin bölgesel olmaktan daha çok küresel bir yapıda tasarlandığı görülmektedir. Üye ülkelerden Nijerya, Afrika'da Gine Körfezi'ni; Mısır, Süveyş Kanalı, Kızıldeniz, Babul Mendep Boğazı ve Aden Körfezi’ni; Türkiye, İstanbul ve Çanakkale Boğazlarıyla, Karadeniz, Ege ve Akdeniz'i; İran, Basra Körfezi, Hürmüz Boğazı ve Umman Denizi'ni; Pakistan ise Umman Denizi'ni kontrol eden konuma sahiptir. Güneydoğu Asya'da tarafına baktığımızda Bangladeş Bengal Körfezi'ne, Malezya Malaka Boğazı'na, Endonezya Sonda ve Lombok Boğazları'na hakimdir (Çelik, 2018).

D-8 ülkeleri arasında ticareti güçlendirmek ve başta döviz kuru riski olmak üzere kırılgan ekonomileri doğrudan etkileyen risklerin ortadan kaldırılması için para birliği kurulması hedeflenmiştir. "İslam Dinarı" olarak adlandırılan bu projenin fikir babaları arasında Prof. Dr. Necmettin Erbakan gelmektedir. İslam Dinarı sistemi, İslam ülkelerinin kendi arasında belirlediği şartlara göre altına dayalı para sistemine geçmesi ve Müslümanların ortak para kullanması olarak ifade edilebilir. İslam Dinarı yani İslam ülkeleri arasında uygulanacak altına dayalı parasal birlik ile ilgili söylemler çeşitli İslam ülkelerinde de dile getirilmektedir. Örneğin Dinarist hareketin merkezi olan Malezya'daki eski Başbakan Mahathir Muhammed, 2011 'de Dinarın uygulanması çağrısında bulunmuştur. Bu adımın Dolar'a karşı bağımlılığın azaltılması ve Müslüman ülkeler arasındaki ticareti arttırılmasına katkı sağlayacağı pek çok platformda da farklı kişiler tarafından da dile getirilmiştir (Arif ve Shabbir, 2019). İslam Dinarı sisteminde altının sadece fiziki olarak muamelelere aracı olmayacağını; teknolojinin getirdiği imkanlardan faydalanarak tam rezervle elektronik olarak da dinar sisteminin uygulanması gerektiği ifade edilmiştir. İslam Dinarı, İslam ülkelerinin ekonomilerini olumsuz yönde etkileyen döviz kuru riskinin bertaraf edilmesi için alternatif bir model olarak sunulmuştur (Meera, 2002). Fakat İslam ülkelerinin parasal birliği sağlamak için ortaya attığı hiçbir proje, çeşitli nedenlerden dolayı hayata geçirilememiştir (Tuğrul, 2019).

Arif ve Shabbir (2019) çalışmasında, faktör hareketliliği, gelir kaynakları, siyasi ve sosyo-ekonomik koşullar açısından İslam ülkeleri arasında büyük farklılıklar bulunduğu için 
böyle bir para birliği oluşumunun İslam ülkeleri için faydasının yanında maliyetinin daha fazla olabileceğini göstermektedir. Bunun yanında APB dikkate alınarak İIT'na üye ülkeler örnemlem olarak seçilmiş ve OPS teorisine göre analiz eden çalışmalar yapılmıştır (Basher, 2015). KİK üyeleri ile APB üyeleri arasında çok büyük farklılıklar olsa Cham (2020)'ın çalışmasında enflasyon, faiz ve mali göstergelere göre bazı KİK üyelerinin APB'nin belirlemiş olduğu yakınsama kriterlerini ve dolayısıyla Euro para sistemine girmek için gerekli şartları sağladığını tespit etmiştir. Bununla birlikte işgücü hareketliliği sınırlı olması ve üye ülkelerin petrol ve doğal gaza bağımlı olmaları nedeniyle talep ve fiyat değişimlerine bağlı olarak dış şoklarla karşı karşıyadırlar. KİK ülkelerini OPS çerçevesinde inceleyen bir diğer çalışma da Benbouziane ve Benamar (2010) tarafından hazırlanmıştır. Çalışmanın sonuca göre ticarete ve diş yatırımlara engel olarak görülen yerel ve ülkeler arası çarpıklıkların varlığı, makroekonomik istikrarı sağlayan ulusal politikaların koordinasyonundaki sorunlar ve bölgesel entegrasyonun derinleşmemesi gibi nedenlerden dolayı OPS çerçevesinde bir parasal birlik kurulmasının mümkün olmadığı görülmektedir.

\section{OPS'nin D-8 ülkeleri için test edilmesi}

Bu bölümde, İslam ülkeleri arasında oluşturulabilecek bir parasal birliğin fizibilitesi D-8 ülkeleri örneklemi üzerinden ampirik olarak incelenmiştir. Döviz kuru, faiz, enflasyon ve dış ticaret değişkenleri arasındaki ilişkinin yönü ve büyüklüğü, ayrıca D-8 ülkelerinin yaşadığı şokların birbirine benzeyip benzemediği çeşitli ekonometrik tekniklerle analiz edilmelidir.

\subsection{Veriler}

Çalışmamızda D-8 ülkelerinin optimum bir para alanı olup olmadığını yani bir parasal birlik potansiyeli taşıyıp taşımadığını test etmek adına döviz kuru, enflasyon, dış ticaret ve faiz değişkenleri birlikte analiz edilmiştir. Çalışmamız 2000 yılı ile 2020 yıllarını kapsayan çeyreklik veriler kullanılmıştır.

Tablo 1: Kullanılan Değişkenler Hakkında Bilgiler

\begin{tabular}{lccc}
\hline Kısaltma & Kullanılan Değișkenler & Dönem & Kaynak \\
\hline Dolar & Amerikan Doları Kuru & 2000Q1-2020Q4 & IMF (2021) \\
Faiz & Mevduat Faiz Oranı Ortalaması & 2000Q1-2020Q4 & IMF (2021) \\
Enflasyon & Tüketici Fiyat Endeksi (2010 Y1lı) & 2000Q1-2020Q4 & IMF (2021) \\
Ticaret & D-8 Ülkelerine Yapılan İhracat ve İthalat Toplamı & 2000Q1-2020Q4 & IMF (2020) \\
\hline
\end{tabular}

\subsection{Yöntem}

Araştırmamızda öncelikle serilerin durağan olup olmadıklarını tespit edebilmek için Genişletilmiş Dickey Fuller (ADF) ve Phillips-Perron (PP) birim kök testleri kullanılmıştır. Daha sonra değişkenlerin durağan olup olmaması ve eşbütünleşmenin varlığına göre VAR 
veya VECM analizinden yararlanılacaktır. Tablo 2'te birim kök testi sonuçları gösterilmiştir.

Çalışmamızda kullanılan veri seti için gecikme uzunluğu belirlenmesinde kriter arasında daha fazla tercih edilen gecikme sayısının dikkate alınması uygun görülmüştür. Johansen eşbütünleşme analizi yapılmadan önce, kurulacak model için en uygun gecikme sayısı belirlenirken FPE, HQ, Akaike ve Schwarz seçim kriterleri sonuçları elde edilmiş fakat uygun gecikme uzunluğu Schwarz seçim kriterine göre belirlenmiştir (Geweke ve Meese, 1981). Tablo 3'te eşbütünleşme sonuçları yer almaktadır. Elde edilen sonuçlara göre; Bangladeş, Mısır için 5; Türkiye ve Pakistan için 4; İran ve Malezya için 3; Endonezya ve Nijerya için ise 2 gecikme uzunluğu belirlenmiştir.

\subsection{Vektör Hata Düzeltme Modeli (VECM)}

Hata düzeltme modeli, zaman serilerinin analizinde kullanılan, kısa ve uzun dönem ilişkisi arasında ortaya çıkan dengesizliğin ve eşbütünleşik değişkenlerin kısa ve uzun dönemli nedensellik ilişkisinin belirlenmesi için kullanılır. İlgili değişkenlerin eşbütünleşik olması halinde standart Granger Nedensellik testinin geçersiz olacağı, seriler arasındaki nedenselliği analiz etmek için hata düzeltme modelinin kullanılması gerektiği belirtilmiştir (Granger, 1988). Eşbütünleşme tahmini seriler arasındaki uzun dönemde dengenin olup olmadığını ortaya koymakta ve fark alma işlemi neticesinde oluşan bilgi kaybına engel olmaktadır. Değişkenler uzun dönem ilişkisine sahip olsa bile kısa dönemli sapmalara sahip olabilirler. Hata düzeltme modeli, kısa dönemli sapmaların ne kadar süre ile düzeltildiğini söylemektedir.

Tablo 2: Birim Kök Testi Sonuçları

\begin{tabular}{|c|c|c|c|c|c|}
\hline & & \multicolumn{2}{|c|}{ ADF Testi } & \multicolumn{2}{|c|}{ PP Testi } \\
\hline Değişkenler & & Sabit & Sabit-Trendli & Sabit & Sabit-Trendli \\
\hline \multirow{2}{*}{ Dolar } & Düzeyde & $\begin{array}{c}\text { BG-, EN-, İR-, } \\
\text { MA-, MI-, Nİ-, PA-, } \\
\text { TR- }\end{array}$ & $\begin{array}{c}\text { BG-, EN-, İR-, } \\
\text { MA-, MI-, Nİ-, PA-, } \\
\text { TR- }\end{array}$ & $\begin{array}{c}\text { BG-, EN-, İR-, } \\
\text { MA-, MI-, Nİ-, PA-, } \\
\text { TR- }\end{array}$ & $\begin{array}{c}\text { BG-, EN-, İR-, } \\
\text { MA-, MI-, Nİ-, } \\
\text { PA-, TR- }\end{array}$ \\
\hline & 1. Fark & $\begin{array}{c}\mathrm{BG}+, \mathrm{EN}+, \mathrm{IIR}+ \\
\mathrm{MA}+, \mathrm{MI}+, \mathrm{NI}+ \\
\mathrm{PA}+, \mathrm{TR}+\end{array}$ & $\begin{array}{c}\mathrm{BG}+, \mathrm{EN}+, \mathrm{I} \mathrm{R}+ \\
\mathrm{MA}+, \mathrm{MI}+, \mathrm{NI}+ \\
\text { PA-, TR+ }\end{array}$ & $\begin{array}{c}\mathrm{BG}+, \mathrm{EN}+, \mathrm{I} \mathrm{R}+ \\
\mathrm{MA}+, \mathrm{MI}+, \mathrm{NI}+ \\
\mathrm{PA}+, \mathrm{TR}+\end{array}$ & $\begin{array}{c}\mathrm{BG}+, \mathrm{EN}+, \mathrm{I} \mathrm{R}+, \\
\mathrm{MA}+, \mathrm{MI}+, \mathrm{NI}+, \\
\mathrm{PA}+, \mathrm{TR}+\end{array}$ \\
\hline \multirow{2}{*}{ Ticaret } & Düzeyde & $\begin{array}{c}\text { BG-, EN-, İR-, } \\
\text { MA-, MI-, Nİ-, PA-, } \\
\text { TR- }\end{array}$ & $\begin{array}{c}\text { BG-, EN-, IR-, } \\
\text { MA-, MI-, Nİ+, } \\
\text { PA-, TR- }\end{array}$ & $\begin{array}{c}\text { BG-, EN-, İR-, } \\
\text { MA-, MI-, Nİ-, PA-, } \\
\text { TR- }\end{array}$ & $\begin{array}{c}\text { BG-, EN-, İR-, } \\
\text { MA-, MI-, Nİ+, } \\
\text { PA-, TR- }\end{array}$ \\
\hline & 1. Fark & $\begin{array}{c}\mathrm{BG}+, \mathrm{EN}+, \mathrm{IR}+, \\
\mathrm{MA}+, \mathrm{MI}+, \mathrm{NI}+, \\
\mathrm{PA}+, \mathrm{TR}+\end{array}$ & $\begin{array}{c}\mathrm{BG}+, \mathrm{EN}+, \mathrm{I} \mathrm{R}+, \\
\mathrm{MA}+, \mathrm{MI}+, \mathrm{NI}+, \\
\mathrm{PA}+, \mathrm{TR}+\end{array}$ & $\begin{array}{c}\mathrm{BG}+, \mathrm{EN}+, \mathrm{IR}+ \\
\mathrm{MA}+, \mathrm{MI}+, \mathrm{NI}+ \\
\mathrm{PA}+, \mathrm{TR}+\end{array}$ & $\begin{array}{c}\mathrm{BG}+, \mathrm{EN}+, \text { IR }+, \\
\mathrm{MA}+, \mathrm{MI}+, \mathrm{NI}+, \\
\mathrm{PA}+, \mathrm{TR}+\end{array}$ \\
\hline
\end{tabular}




\begin{tabular}{|c|c|c|c|c|c|}
\hline \multirow{2}{*}{ Faiz } & Düzeyde & $\begin{array}{c}\text { BG-, EN-, İR-, } \\
\text { MA-, MI+, Nİ-, } \\
\text { PA-, TR- }\end{array}$ & $\begin{array}{l}\text { BG-, EN+, İR-, } \\
\text { MA-, MI-, Nİ+, } \\
\text { PA-, TR- }\end{array}$ & $\begin{array}{c}\text { BG-, EN- İR-, MA-, } \\
\text { MI-, Nİ-, PA-, TR- }\end{array}$ & $\begin{array}{c}\text { BG-, EN-, İR-, } \\
\text { MA-, MI-, Nİ-, } \\
\text { PA-, TR- }\end{array}$ \\
\hline & 1. Fark & $\begin{array}{c}\mathrm{BG}+, \mathrm{EN}+, \mathrm{I} \mathrm{R}+ \\
\mathrm{MA}+, \mathrm{MI}+, \mathrm{NI}+ \\
\mathrm{PA}+, \mathrm{TR}+\end{array}$ & $\begin{array}{c}\mathrm{BG}+, \mathrm{EN}+, \mathrm{I} \mathrm{R}+ \\
\mathrm{MA}+, \mathrm{MI}+, \mathrm{NI}+ \\
\mathrm{PA}+, \mathrm{TR}+\end{array}$ & $\begin{array}{c}\mathrm{BG}+, \mathrm{EN}+, \mathrm{I} \mathrm{R}+ \\
\mathrm{MA}+, \mathrm{MI}+, \mathrm{NI}+ \\
\mathrm{PA}+, \mathrm{TR}+\end{array}$ & $\begin{array}{c}\mathrm{BG}+, \mathrm{EN}+, \text { İR }+, \\
\mathrm{MA}+, \mathrm{MI}+, \mathrm{NI}+, \\
\mathrm{PA}+, \mathrm{TR}+\end{array}$ \\
\hline \multirow{2}{*}{ Enflasyon } & Düzeyde & $\begin{array}{c}\text { BG-, EN-, İR-, } \\
\text { MA-, MI-, Nİ-, PA-, } \\
\text { TR- }\end{array}$ & $\begin{array}{c}\text { BG-, EN-, İR-, } \\
\text { MA-, MI-, Nİ-, PA-, } \\
\text { TR- }\end{array}$ & $\begin{array}{c}\text { BG-, EN-, İR-, } \\
\text { MA-, MI-, Nİ-, PA-, } \\
\text { TR- }\end{array}$ & $\begin{array}{c}\text { BG-, EN-, İR-, } \\
\text { MA-, MI-, Nİ-, } \\
\text { PA-, TR- }\end{array}$ \\
\hline & 1. Fark & $\begin{array}{c}\text { BG-, EN+, İR-, } \\
\text { MA+, MI-, Nİ+, } \\
\text { PA-, TR- }\end{array}$ & $\begin{array}{c}\mathrm{BG}+, \mathrm{EN}+, \mathrm{IR}+, \\
\mathrm{MA}+, \mathrm{MI}+, \mathrm{NI}+, \\
\mathrm{PA}+, \mathrm{TR}+\end{array}$ & $\begin{array}{c}\mathrm{BG}+, \mathrm{EN}+, \mathrm{I} \mathrm{R}+ \\
\mathrm{MA}+, \mathrm{MI}+, \mathrm{NI}+ \\
\mathrm{PA}+, \mathrm{TR}+\end{array}$ & $\begin{array}{c}\mathrm{BG}+, \mathrm{EN}+, \text { İR }+, \\
\mathrm{MA}+, \mathrm{MI}+, \mathrm{NI}+, \\
\mathrm{PA}+, \mathrm{TR}+\end{array}$ \\
\hline
\end{tabular}

Not: ADF testinde uygun gecikme uzunluğu Schwarz bilgi kriterine göre belirlenmiştir. PP testinde "Barlett kernel" ve "Newey West bandwith" kriterleri tercih edilmiștir.

BG, EN, İR, MA, MI, NI, PA ve TR sırasıyla Bangladeş, Endonezya, İran, Malezya, Mısır, Nijerya, Pakistan ve Türkiye’yi ifade etmektedir. Ülke kısaltmaları yanında yer alan + ve - işaretleriyse sırasıyla durağanlığın varlığını ve yokluğunu göstermektedir.

Tablo 3: Eşbütünleşme Testi Sonuçları

\begin{tabular}{lc}
\hline \multicolumn{2}{l}{ Trace İstatistiğine Göre Eşbütünleşme Testi } \\
\hline Eşbütünleşme Hipotezleri & Ülkeler \\
\hline Sifır $\left(\mathrm{H}_{0}: \mathrm{r}=0\right)$ & BG, EN, İR, MA, MI, Nİ, PA, TR \\
En çok $1\left(\mathrm{H}_{0}: \mathrm{r} \leq 1\right)$ & BG, MA, TR \\
En çok $2\left(\mathrm{H}_{0}: \mathrm{r} \leq 2\right)$ & BG \\
En çok $3\left(\mathrm{H}_{0}: \mathrm{r} \leq 3\right)$ & IR, TR \\
\hline Max-Eigen İstatistiğine Göre Eşbütünleşme Testi & \\
\hline Eşbütünleşme Hipotezleri & Ülkeler \\
Sifır $\left(\mathrm{H}_{0}: \mathrm{r}=0\right)$ & BG, EN, MI, Nİ, PA, TR \\
En çok $1\left(\mathrm{H}_{0}: \mathrm{r} \leq 1\right)$ & BG \\
En çok $2\left(\mathrm{H}_{0}: \mathrm{r} \leq 2\right)$ & BG \\
En çok $3\left(\mathrm{H}_{0}: \mathrm{r} \leq 3\right)$ & IR, TR \\
\hline
\end{tabular}

BG, EN, İR, MA, MI, Nİ, PA ve TR sırasıyla Banglades, Endonezya, İran, Malezya, Mısır, Nijerya, Pakistan ve Türkiye'yi ifade etmektedir. Ülke kısaltmaları yanında yer alan + ve - işaretleriyse sırasıyla durağanlığın varlığını ve yokluğunu göstermektedir.

Bağımsız değişkenlerin istatistiksel olarak anlamlı olması, değişkenler arasındaki kısa dönem nedenselliği gösterirken, hata düzeltme katsayısı negatif ve istatistiki olarak da anlamlı olması halinde ilgili değişkenler arasında uzun dönemli bir nedensellik ilişkisinin varlığından söz edilmektedir. Bu katsayının negatif çıkması değişkenler arasındaki dengenin bozulması halinde uzun dönemde tekrar dengeye yaklaşılacağını, pozitif çıkması halinde ise giderek dengeden uzaklaşılacağını göstermektedir. 
Tablo 4: Kısa ve Uzun Dönem Nedensellik Sonuçları

\begin{tabular}{lcc}
\hline Değişkenler & Kısa Dönem & Uzun Dönem \\
\hline Dolar $\Rightarrow$ Enflasyon & Endonezya, Mısır, Pakistan, Türkiye & Türkiye \\
Dolar $\Rightarrow$ Faiz & Bangladeş, Mısır, Pakistan & Nijerya \\
Dolar $\Rightarrow$ Ticaret & Malezya & Endonezya \\
Enflasyon $\Rightarrow$ Dolar & Nijerya, Pakistan & Malezya, Nijerya \\
Enflasyon $\Rightarrow$ Faiz & İran, Malezya, Pakistan, Türkiye & Nijerya \\
Enflasyon $\Rightarrow$ Ticaret & Bangladeş, & Endonezya \\
Faiz $\Rightarrow$ Dolar & Endonezya & Malezya, Nijerya \\
Faiz $\Rightarrow$ Enflasyon & İran, Pakistan & Türkiye \\
Faiz $\Rightarrow$ Ticaret & İran & Endonezya \\
Ticaret $\Rightarrow$ Dolar & Bangladeş, İran, Misır & Malezya, Nijerya \\
Ticaret $\Rightarrow$ Enflasyon & Bangladeş, Misır & Türkiye \\
Ticaret $\Rightarrow$ Faiz & - & Nijerya \\
\hline
\end{tabular}

Modelin analiz edilmesi sonucunda hata düzeltme terimi katsayısının istatistiksel olarak anlamlı ve negatif olması uzun dönem ilişkinin bulunduğunu göstermektedir. Uzun dönemde ECT katsayısının negatif olması ilgili değişkenler arasındaki dengesizliğin azaldığına işaret etmektedir. Malezya ve Nijerya'da Enflasyon, Faiz ve Ticaret'ten Dolar'a doğru uzun dönem nedensellik olduğu tespit edilmiştir. Türkiye'de Dolar ve Faiz'den Enflasyon'a doğru bir uzun dönem nedensellik ilişkisi olduğu görülmüştür. Buna karşın Endonezya, Mısır, Pakistan, Türkiye için Dolar'dan Enflasyon'a, İran, Malezya, Pakistan, Türkiye için ise Enflasyon'dan Faiz'e doğru kısa dönem bir nedensellik bulunmuştur. Buna ek olarak Faiz'den Enflasyon'a doğru kısa dönemde bir etkileşimin İran ve Pakistan için geçerli olduğu sonucuna ulaşılmıştır. Tablo 5,6,7,8,9,10 ve 11 'de değişkenlerden elde edilen etkitepki fonksiyonu (EFT) grafiklerine yer verilmiştir.

Dolar'ın Faiz'e tepkisini gösteren ETF grafiklerine göre Bangladeş, Mısır, Endonezya ve İran'da Faiz değişkenine uygulanan pozitif bir şoka karşı Dolar da pozitif bir tepki vermekte fakat bu etki 2-4 dönem sonra negatife dönmektedir. Malezya ve Türkiye'de genel olarak Dolar'ın sürekli pozitif bir tepkisi görülmektedir. Nijerya ve Pakistan'da ise Faiz'in Dolar üzerindeki etkisi genel olarak negatif yönlü olduğu tespit edilmiştir. 
Tablo 5: Dolar'ın Faiz'e Tepkisi

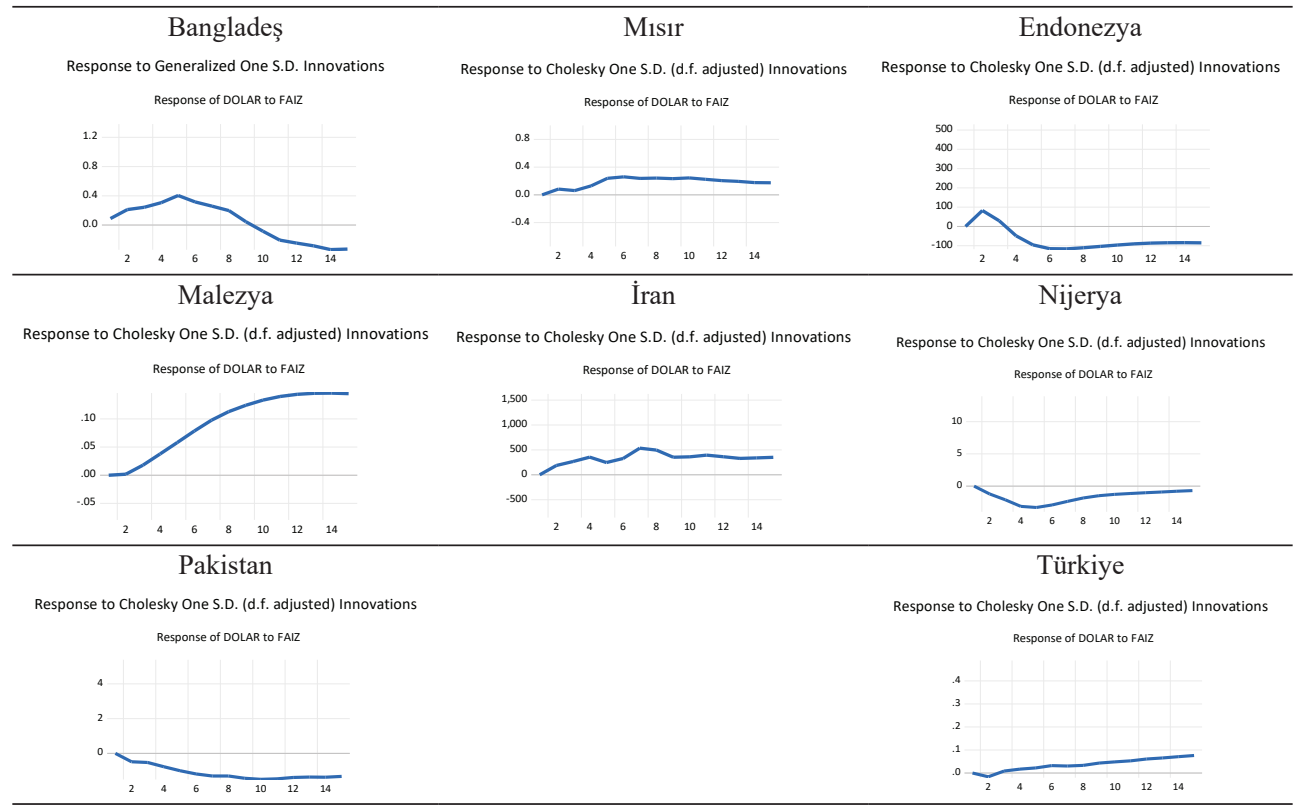

Tablo 6: Faiz'in Dolar'a Tepkisi

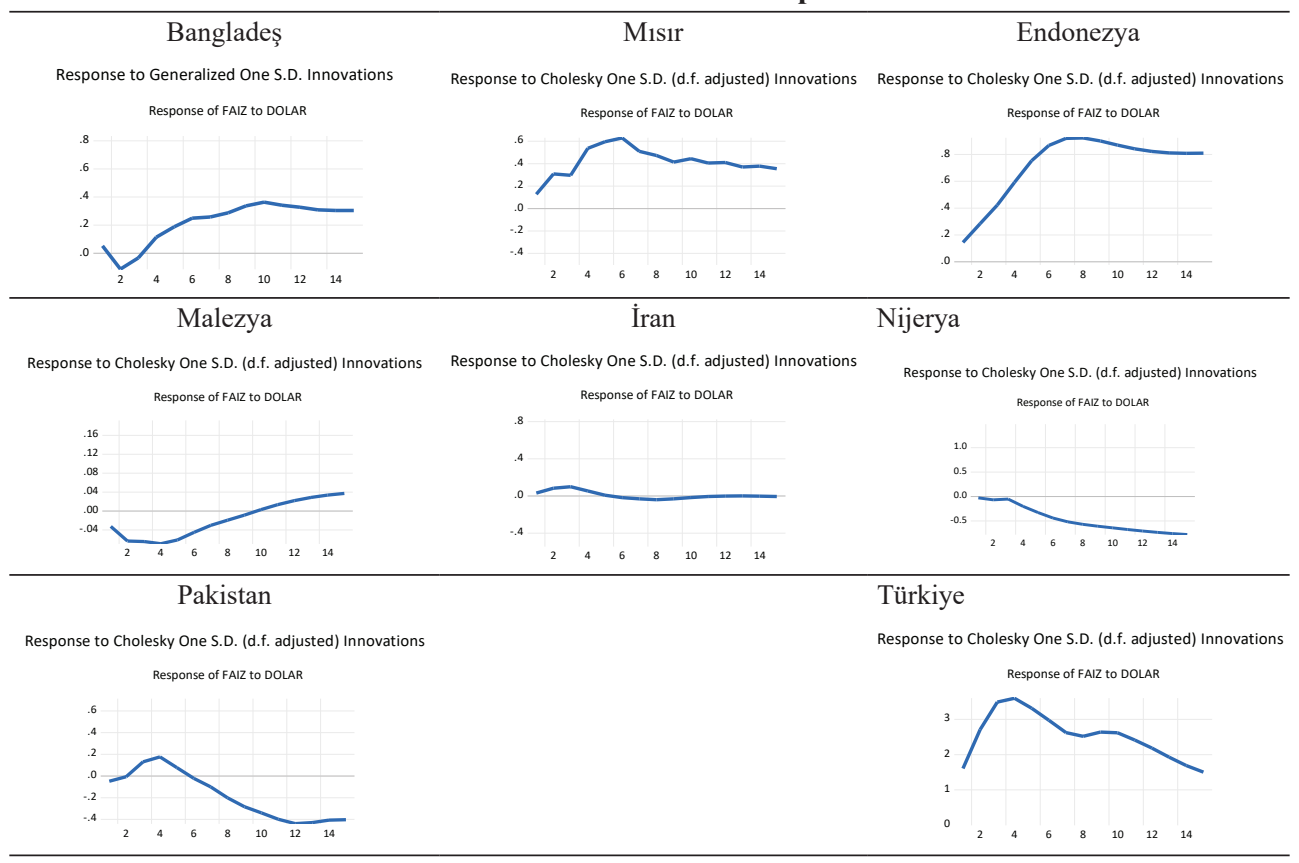


Faiz'in Dolar'a tepkisini gösteren ETF grafiklerine göre Mısır, Endonezya, Pakistan ve Türkiye'de Dolar değişkenine uygulanan pozitif bir şoka karşı Faiz değişkeni 4-6. döneme kadar pozitif tepki göstermiştir. Bu aşamadan sonra bu tepkinin etkisi azalmış, Pakistan'da ise negatif bir tepki dönüşmüştür. İran'da Faiz'in Dolar'a karşı pozitif bir tepki görülmesine karşın 6. dönemden sonra bu tepki durağanlaşmıştır. Bangladeş ve Malezya'da ise Faiz değişkenin tepkisi başlarla negatifken, bir süre sonra pozitif tepki gösterdiği görülmüştür.

Tablo 7: Faiz'in Enflasyon'a Tepkisi

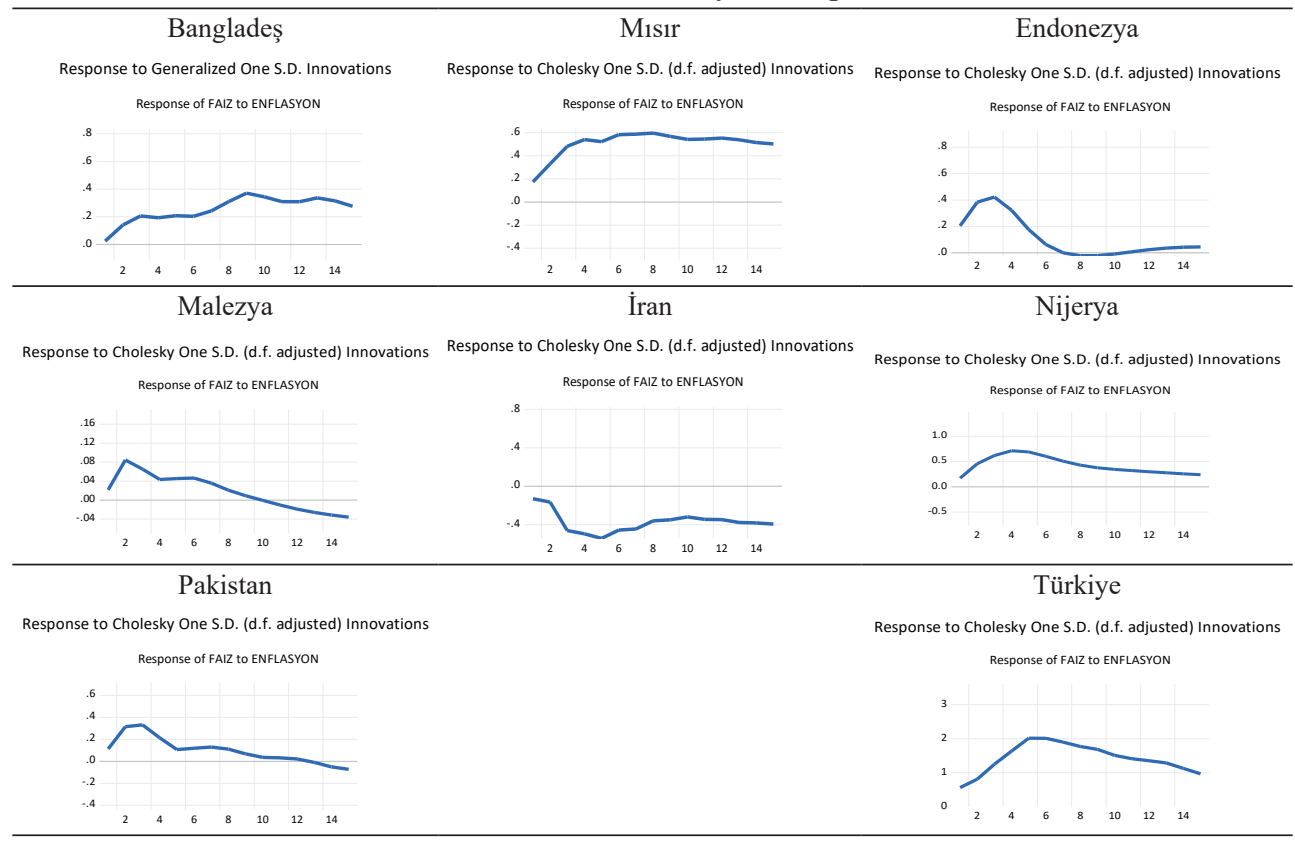

Enflasyon değişkenine uygulanan bir birim pozitif şokun Faiz değişkeni üzerindeki etkisini incelediğimizde; İran hariç tüm D-8 ülkelerinin bu şoka karşı genel olarak pozitif tepki verdiği tespit edilmiştir. Pozitif tepki 3-4. döneme kadar hızla artmasına karşın bu periyottan sonra etkisini azaltmıştır. Faiz'in Enflasyon'a tepkisi İran üzerinde incelendiğinde Faiz değişkeninin genel olarak negatif bir tepki verdiği görülmüş, 5. dönemde ise bu tepki en yüksek noktaya ulaşmıştır.

Enflasyon değişkenine uygulanan bir birim pozitif şokun Dolar değişkeni üzerindeki etkisini incelediğimizde; Endonezya hariç tüm D-8 ülkelerinin bu şoka karşı genel olarak pozitif tepki verdiği tespit edilmiştir. Nijerya ve Mısır'daki pozitif tepki 4-5. döneme kadar hızla artmasına karşın bu periyottan sonra durağanlaşmıştır. Endonezya'da Dolar değişkeninin tepkisi 5. döneme kadar pozitif seyredenken bu aşamadan sonra negatif tepki vermeye başladığı tespit edilmiştir. 
Tablo 8: Dolar'ın Enflasyon'a Tepkisi

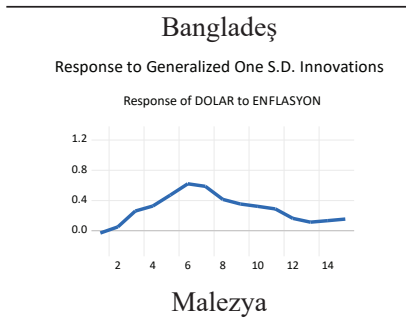

Response to Cholesky One S.D. (d.f. adjusted) Innovations

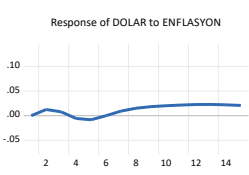

Pakistan

Response to Cholesky One S.D. (d.f. adjusted) Innovations

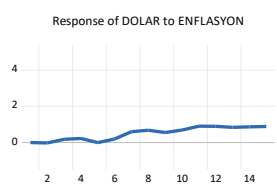

Misir

Response to Cholesky One S.D. (d.f. adjusted) Innovations

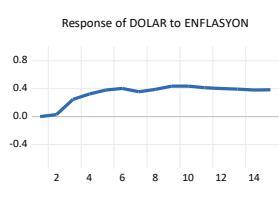

İran

Response to Cholesky One S.D. (d.f. adjusted) Innovations

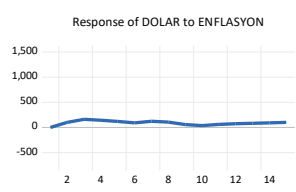

Endonezya

Response to Cholesky One S.D. (d.f. adjusted) Innovations

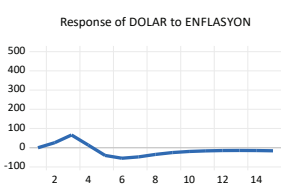

Nijerya

Response to Cholesky One S.D. (d.f. adjusted) Innovations

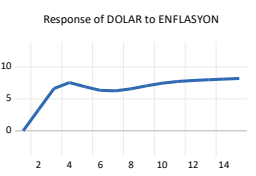

Türkiye

Response to Cholesky One S.D. (d.f. adjusted) Innovations Response of DOLAR to ENFLASYON

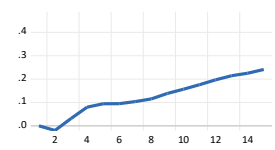

Tablo 9: Enflasyon'un Dolar'a Tepkisi

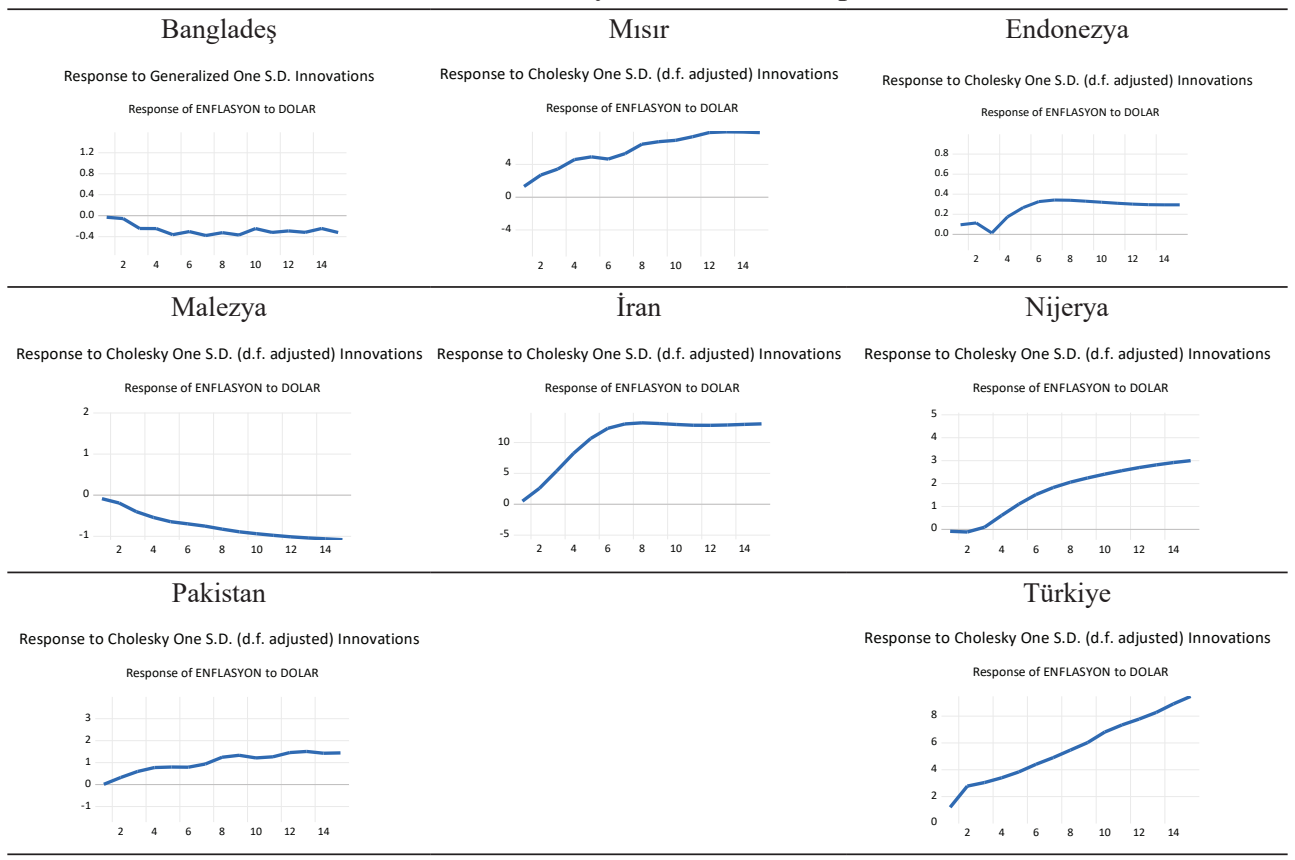


Dolar değişkenine uygulanan bir birim pozitif şokun Enflasyon değişkeni üzerindeki etkisini incelediğimizde; Bangladeş ve Malezya hariç tüm D-8 ülkelerinin bu şoka karş1 genel olarak pozitif tepki verdiği tespit edilmiştir. Endonezya'da Dolar değişkeninin tepkisi 2. döneme kadar durağan, 4. döneme kadar ise azalan bir trend izlemesine karşın 4. dönemden sonra artış eğilimi göstermiştir. İran'da ise 6. döneme kadar artış eğilimi göstermiş, bu aşamadan sonra durağan bir seyir izlemiştir.

Tablo 10: Enflasyon'un Faiz'e Tepkisi

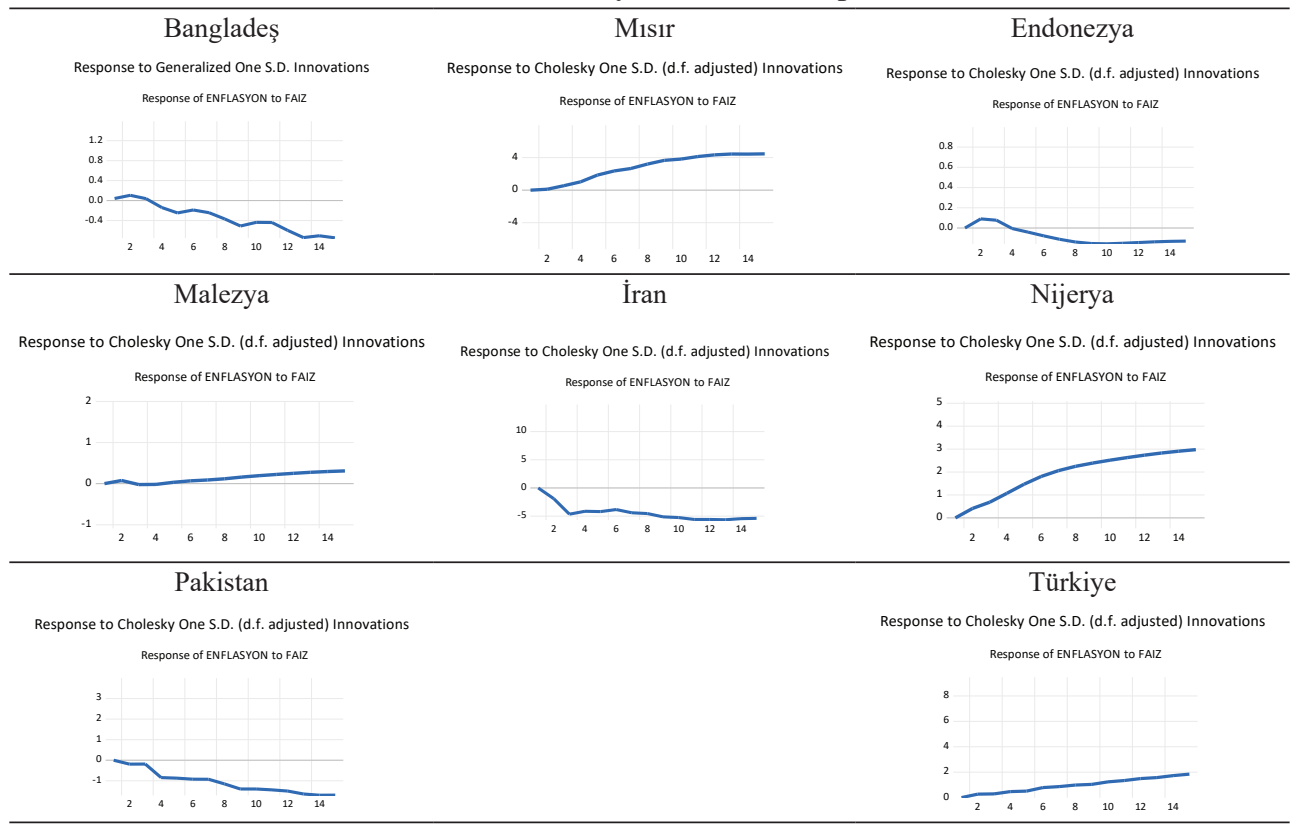

Faiz değişkenine uygulanan bir birim pozitif şokun Enflasyon değişkeni üzerindeki etkisini incelediğimizde; Türkiye, Nijerya, Mısır ve Malezya'da bu şoka karşı genel olarak pozitif tepki verdiği tespit edilmiştir. Pakistan ve İran'da ise Enflasyon'un Faiz'e tepkisi negatifken Endonezya ve Bangladeş’te pozitif başlayan tepki 4. dönemde negatif olarak devam etmiştir.

Dolar değişkenine uygulanan bir birim pozitif şokun Ticaret değişkeni üzerindeki etkisini incelediğimizde; Bangladeş ve Malezya hariç tüm D-8 ülkelerinin bu şoka karşı genel olarak negatif tepki verdiği tespit edilmiştir. Bangladeş’te Ticaret değişkeninin tepkisi pozitif ve negatif olarak dalgalı bir seyirde gerçekleşmiştir.

\subsection{Varyans Ayrıştırması}

Varyans ayrıştırması analizi, ilgili değişkenlerin hata varyansının, modeldeki diğer değişkenlerin şoklarına ve kendi şoklarına bağlı olarak nasıl değiştiğini göstermektedir. 
Varyans ayrıştırması sayesinde sistemdeki ilgili değişkenlerin varyanslarındaki değişmenin kaynakları tespit edilebilirken, bu değişimin değişkenin kendisinden mi yoksa diğer değişkenlerden mi kaynaklandığı yüzdesel olarak belirlenebilmektedir. D-8 ülkerine ait Dolar, Enflasyon, Faiz ve Ticaret değişkenlerini 15 dönemlik varyans ayrıştırması analizi yapılmıştır.

Tablo 11: Ticaret'in Dolar'a Tepkisi

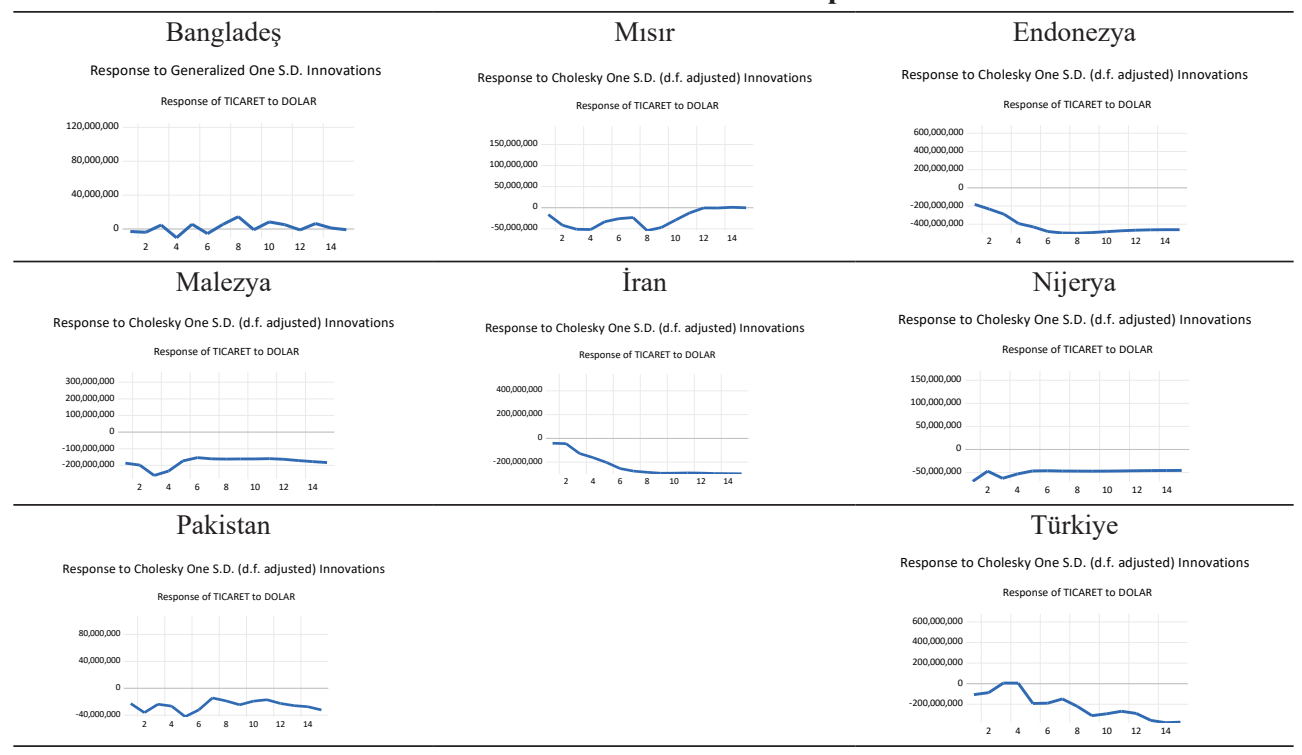


Tablo 12: D-8 Ülkelerinin Dolar Varyans Ayrıştırması

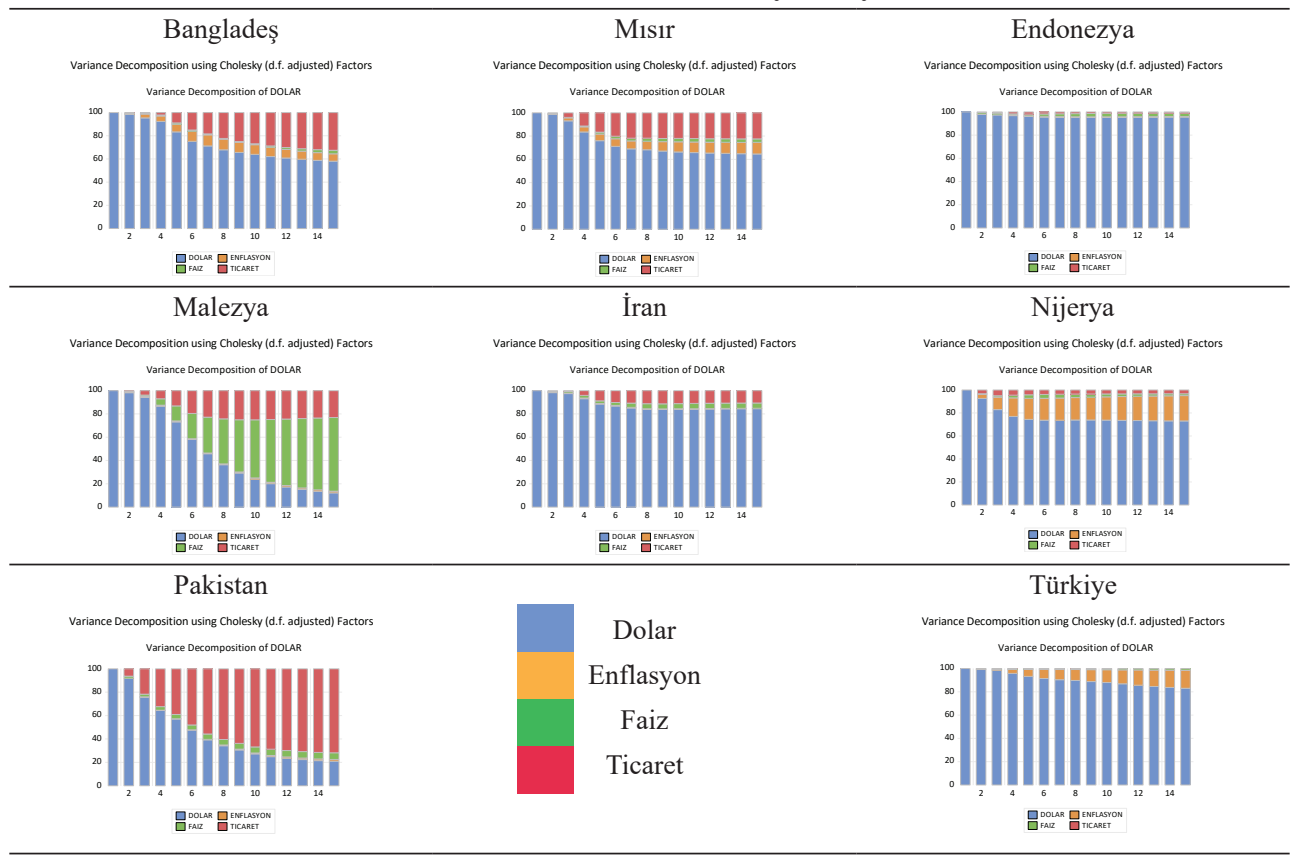

Dolar değişkeni için varyans ayrıştırması sonuçlarını incelediğimizde; Malezya ve Pakistan hariç D-8 ülkelerinin Dolar değişkeni yine Dolar tarafından açıklanmaktadır. Bangladeş, Mısır ve Malezya'da Ticaret' in Dolar'ı açıklaması 15 dönem boyunca benzerlik gösterirken, Nijerya ve Türkiye'de 15 dönem boyunca ortalama \%15-\%20 oranında Enflasyon tarafından açıklanmaktadır. Buna karşın Malezya'da 5. dönemde yaklaşık \%20 oranında Faiz ile açıklanırken bu oran 15. dönemde \%65'e kadar yükselmiştir. Dolar değişkeninin kendisiyle en fazla oranda açıklandığı ülke ise Endonezya'dır. Endonezya'da 15 dönem boyunca Dolar'ın kendisini açıklama oranı yaklaşık \%95 seviyelerinde olduğu tespit edilmiştir. 
Tablo 13: D-8 Ülkelerinin Enflasyon Varyans Ayrıştırması

\begin{tabular}{|c|c|c|}
\hline Bangladeş & Misir & Endonezya \\
\hline Variance Decomposition using Cholessy (d.f. adjusted) Factors & Variance Decomposition using Cholesky (d.f. adjusted) Factors & Variance Decomposition using Cholesky (d.f. adjusted) Factors \\
\hline Variance Decomposition of ENELLSYYoN & Variance Decomposition of ENELASYON & Variance Decomposition of ENFLASYON \\
\hline 10III & 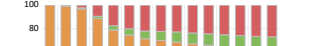 & HAD \\
\hline 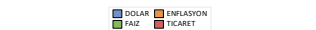 & 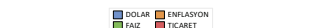 & 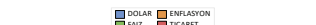 \\
\hline Malezya & İran & Nijerya \\
\hline Variance Decomposition using Cholesky (d.f. adjusted) Factors & Variance Decomposition using Cholesky (d.f. adjusted) Factors & Variance Decomposition using Cholesky (d.f. adjusted) Factors \\
\hline Variance Decomposition of ENELLSSYN & Variance Decomposition of ENFLASYON & Variance Decomposition of ENFLASYON \\
\hline${ }_{80}^{100}$ & HAPHA| & | \\
\hline 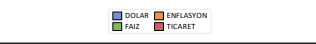 & 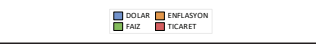 & 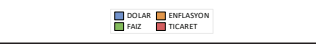 \\
\hline Pakistan & & Türkiye \\
\hline Variance Decomposition using Cholesky (d.f. adjusted) Factors & & Variance Decompossition using Choleskyy (d.f. adjusted) Factors \\
\hline Variance Decomposition of ENFLASYON & Dolar & Varanace Decomposition of ENELASYON \\
\hline${ }_{80}^{100}$ & Enflasyon & \\
\hline & Faiz & \\
\hline & & \\
\hline 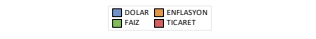 & & 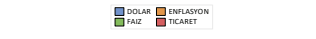 \\
\hline
\end{tabular}

Enflasyon değişkeni için varyans ayrıştırması sonuçlarını incelediğimizde; Bangladeş, Mısır ve Türkiye hariç D-8 ülkelerinin Enflasyon değişkeni yine Enflasyon tarafından açıklanmaktadır. Genel olarak Enflasyon değişkeni İran, Mısır ve Türkiye'de Dolar tarafından, Bangladeş’te Ticaret tarafından açıklanmaktadır. Endonezya ve Pakistan için varyans ayrıştırma sonuçları benzerlik göstermektedir. 1. dönemde Enflasyon değişkeni Ticaret ile açıklanamazken devam eden süreçte bu oran hızla artmış ve 8. dönemde yaklaşık $\% 30$ oranında açıklanmıştır.

Faiz değişkeni için varyans ayrıştırması sonuçlarını incelediğimizde; Bangladeş, Malezya, İran ve Niyerya ülkelerinin Faiz değişkeni yine Faiz tarafından açıklanmaktadır. Genel olarak Faiz değişkeni Pakistan'da Ticaret tarafından, Türkiye ve Endonezya'da ise Dolar tarafından açıklanmaktadır. 15 dönem varyans ayrıştırma oranı ortalamasına baktığımızda Mısır'da Faiz değişkeni yaklaşık \%40 oranında, İran’da ise yaklaşık \%20 oranında açıklanmaktadır. 
Tablo 14: D-8 Ülkelerinin Faiz Varyans Ayrıştırması

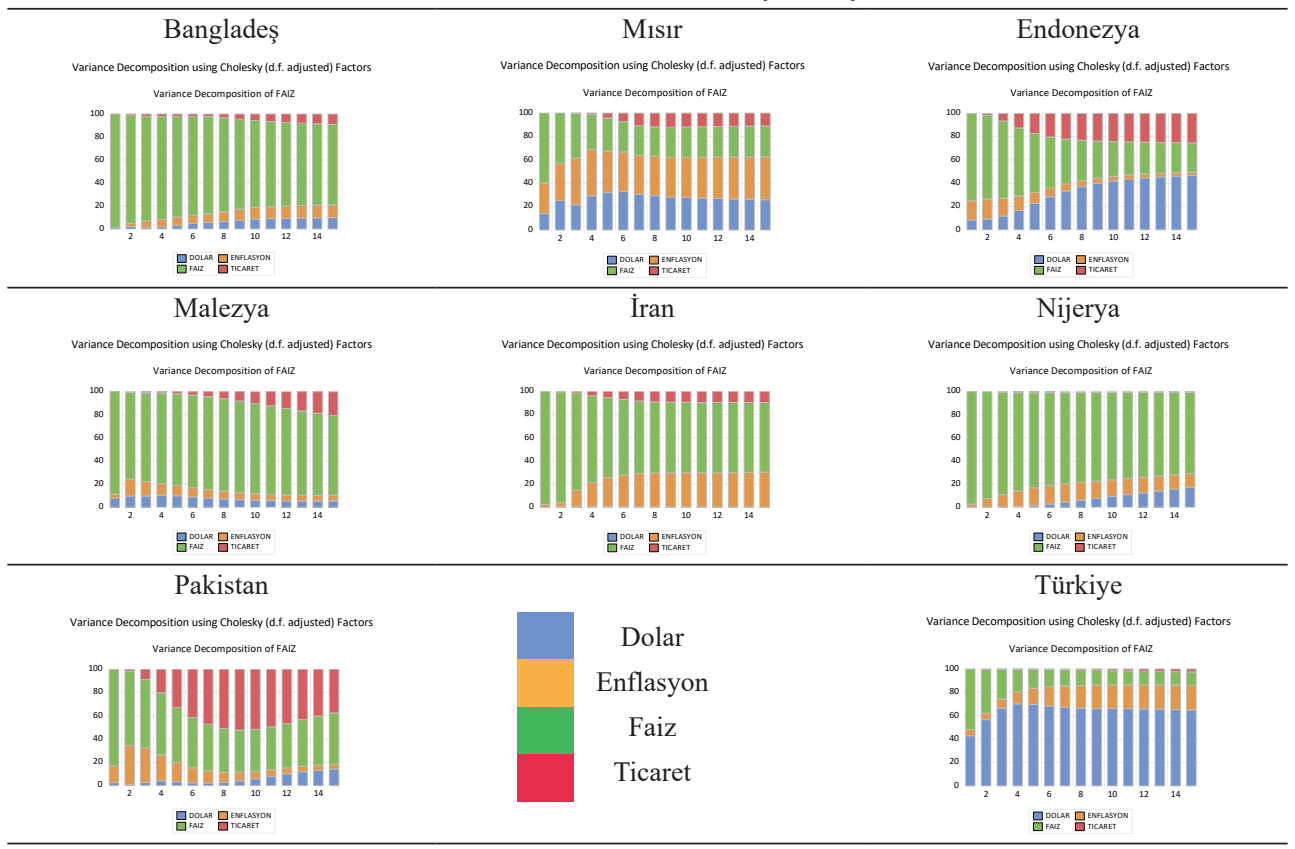

Tablo 15: D-8 Ülkelerinin Ticaret Varyans Ayrıştırması

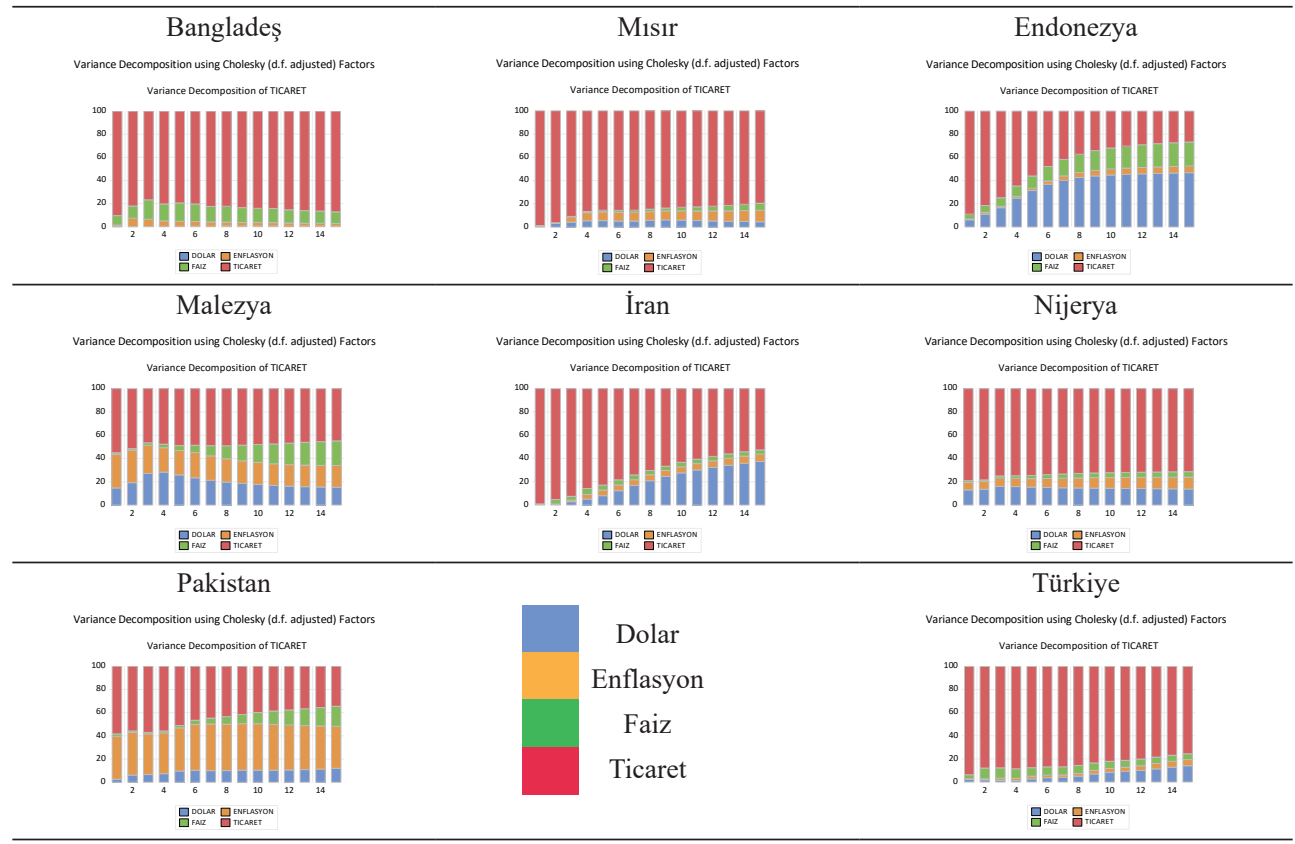


Ticaret değiş̧keni için varyans ayrıştırması sonuçlarını incelediğimizde; Endonezya, Malezya ve Pakistan hariç olmak üzere D-8 ülkelerine ait Ticaret değişkeni yine Ticaret tarafından açıklanmaktadır. Ticaret değişkeni 15 dönem boyunca ortalama Pakistan'da yaklaşık \%40 oranında Enflasyon'la açıklanırken, Malezya'da bu rakam \%20 oranında gerçekleşmiştir. Buna karşın Endonezya'da Ticaret değişkeni ortalama \%35 oranında Dolar'la açıklandığı tespit edilmiştir.

\section{TARTIŞMA ve SONUÇ}

Ülkelerin belirli alanlarda birlikte hareket ederek ekonomik entegrasyona zemin hazırlayacak çalışmalar yapması İslam ülkeleri tarafından da tecrübe edilmiştir. Bu tecrübe Avrupa Birliği (AB) gibi kapsamlı ve derinden olmasa da İslam ülkeleri arasında dayanışmanın sağlanması amaçlanmıştır. Avrupa merkezli ekonomik dayanışma ve entegrasyon çalışmalarının akabinde İslam ülkeleri de öncelikli olarak ekonomik ve siyasi dayanışmaya zemin hazırlayacak örgütler kurmuşlardır. Bu örgütlerin en kapsamlısı ve eskisi 1969 yılında kurulan ve 57 üye ülkeyi kapsayan İİT’dır. Bu teşkilatın sağladığı ekonomik altyap1, AB gibi bir ekonomik entegrasyon sürecinden ziyade daha çok üyeler arasında dayanışmayı sağlayan bir yapıda tasarlanmıştır. AB'nin aksine İslam dünyası tam olarak bir ekonomik entegrasyon sağlayamadığı için Euro sistemi gibi bir ortak para sistemine geçiş yapması mümkün olmamıştır. Özellikle Doları'ın günümüzdeki konumu, her ne kadar uluslararası ticareti kolaylaştırsa da İslam ülkeleri gibi kırılgan ve gelişmekte olan ülkeler için döviz kuru riskini beraberinde getirmektedir.

57 İİT üyesi arasında, siyasi ve ekonomik anlamda önemli derecede özgül ağırlığa sahip ülkelerin kurduğu D-8, başta Doğrudan Yabancı Yatırım (DYY) ve döviz rezervi eksikliği yaşayan bazı ekonomik sorunların kronikleştiği gelişmekte olan kırılgan ülkelerdendir. $\mathrm{Bu}$ ülkelerin DYY çekmesi halinde kalkınma sürecini hızlandırmalarına yardımcı olabilir. Bununla birlikte, sermaye akışı ve doğrudan yabancı yatırım, verimli bir sermaye ve finansal piyasalara ihtiyaç duymaktadır. D-8 ülkelerinin ekonomik entegrasyon sağlamaları, bunun sonucunda parasal birliği tesis etmeleri halinde yaşadıkları kur riskleri bertaraf edilebilir ve uzun vadeli yatırımı çekebilir.

Çalışmamızda İIT'na üye 57 ülkenin rol model olarak kabul edeceği D-8 ülkelerinin oluşturacağı parasal birliğin OPS oluşturabilirliği araştırılmıştır. Bu potansiyeli test etmek için döviz kuru, enflasyon, faiz ve dış ticaret değişkenleri VECM yöntemi üzerinden analiz edilmiştir. Buna ek olarak Granger nedensellik, etki-tepki fonksiyonu ve varyans ayrıştırması kullanılarak D-8 ülkelerinin yaşadıkları şokların benzerliği test edilmiştir.

Malezya ve Nijerya'da Enflasyon, Faiz ve Ticaret'ten Dolar'a uzun dönemli bir Granger nedensellik olduğu tespit edilirken, Türkiye'de Dolar ve Faiz'den Enflasyon'a doğru bir 
uzun dönemde nedensellik ilişkisi olduğu görülmüştür. Buna karşın Endonezya, Mısır, Pakistan, Türkiye için Dolar'dan Enflasyon'a, İran, Malezya, Pakistan, Türkiye için ise Enflasyon'dan Faiz'e doğru kısa dönem bir nedensellik bulunmuştur. Buna ek olarak Faiz'den Enflasyon'a doğru kısa dönemde bir etkileşimin İran ve Pakistan için geçerli olduğu sonucuna ulaşılmıştır.

Etki-tepki fonksiyonu ve varyans ayrıştırma sonuçlarını beraber incelediğimizde, D-8 ülke grubunun OPS'ye uygun olmadığı görülmüştür. Fakat D-8 içerisinde bir altgrup olarak düşünülebilecek Türkiye, Nijerya, Mısır ve Malezya'nın ilgili değişkenlerinde yaşanan şokların benzer olduğu tespit edilmiştir. Bu ülkeler her ne kadar coğrafi olarak birbirine yakın olmasa da tesis edilecek parasal birlikte şokların simetrik olma kriteri açısından OPS gerekliliklerini yerine getirebilecektir. Kazerooni ve Razzaghi (2014)'nin yapmış oldukları çalışmada, elde ettiğimiz sonuçlara benzer şekilde D-8 ülkelerinin tamamının OPS için uygun olmadığı fakat Malezya, Nijerya, Türkiye ve Pakistan için yapısal şokların simetrik olduğu tespit edilmiştir.

Parasal birlikleri sürdürülebilir kılmak için sadece şokların benzerliği bir gösterge olarak kabul edilmemeli, birliğe üye olacak ülkelerin ekonomik, mali ve finansal entegrasyon seviyelerinin yakınsaması gerekmektedir. APB'ye zemin hazırlamak, uzun süreli bir hazırlık aşamasının tamamlanması sonucunda gerçekleştirildiği unutulmamalıdır ki neredeyse 10 yıldan fazla bir hazırlık süreci sonunda başarılı bir parasal birliğe adım atılabilmiştir. İslam ülkelerinin özelde de D-8'in niyet ettikleri parasal birliği tesis edebilmesi APB'de olduğu gibi yıllar öncesinde oluşturulan bir program çerçevesinde gerçekleştirilmelidir.

\footnotetext{
Hakem Değerlendirmesi: Dış bağımsız.

Yazar Katkıları: Çalışma Konsepti/Tasarım- M.S., Ş.G.; Veri Toplama- M.S.; Veri Analizi/Yorumlama- M.S., Ş.G.; Yazı TaslağıM.S., Ş.G.; İçeriğin Eleştirel İncelemesi- M.S., Ş.G.; Son Onay ve Sorumluluk- M.S., Ş.G.

Çıkar Çatışması: Yazarlar çıkar çatışması beyan etmemişlerdir.

Finansal Destek: Yazarlar finansal destek beyan etmemişlerdir.

Peer-review: Externally peer-reviewed.

Author Contributions: Conception/Design of Study- M.S., Ş.G.; Data Acquisition- M.S. Data Analysis/Interpretation- M.S., Ş.G.; Drafting Manuscript- M.S., Ş.G. ; Critical Revision of Manuscript- M.S., S..G.; Final Approval and Accountability- M.S., Ş.G Conflict of Interest: The author has no conflict of interest to declare.

Grant Support: Authors declared no financial support.
}

\section{Kaynakça/References}

Arif, A. \& Shabbir, M. S. (2019). Common currency for Islamic countries: is it viable? Transnational Corporations Review, 11(3), 222-234. doi:10.1080/19186444.2019.1657330

Basher, S. (2015). Regional initiative in the Gulf Arab States: the search for a common currency. International Journal of Islamic and Middle Eastern Finance and Management, 8(2), 185-202. doi:10.1108/ IMEFM-04-2014-0037 
Benbouziane, M. \& Benamar, A. (2010). Could GCC countries achieve an Optimal Currency Area? Middle East Development Journal, 2(2), 203-227. doi:10.1142/S179381201000023X

Bordo, M. \& Jonung, L. (2003). The future of EMU: what does the history of monetary unions tell us? F. Capie ve G. E. Wood (Ed.), Monetary Unions Theory, History, Public Choice içinde (ss. 42-69). Cambridge, MA. doi: $10.3386 /$ w7365

Çelik, S. (2018). İslam Birliğine açılan kapı: D-8. Journal of International Social Research, 11(58), 271-285. doi:10.17719/jisr.2018.2539

Cham, T. (2020). Is the GCC an optimum currency area (OCA)? Empirical answers from co-movements. International Journal of Islamic and Middle Eastern Finance and Management, 13(5), 873-890. doi:10.1108/ IMEFM-06-2018-0198

Couharde, C., Coulibaly, I., Guerreiro, D. \& Mignon, V. (2013). Revisiting the theory of optimum currency areas: Is the CFA franc zone sustainable? Journal of Macroeconomics, 38, 428-441. doi:10.1016/j.jmacro.2013.07.011

De Grauwe, P. (2017). Parasal Birlik Ekonomisi. (U. Utkulu ve G. Güreşçi, Ed.). İstanbul: Nobel Yayınları.

Evlimoğlu, U. (2005). Avrupa'da parasal bütünleşme, sonrasındaki ekonomik gelişmeler ve Türkiye. (Yayımlanmamış yüksek lisans tezi). Adnan Menderes Üniversitesi Sosyal Bilimler Enstitüsü, Aydın.

Fleming, J. M. (1971). On exchange rate unification. The Economic Journal, 71(323), 467-488.

Granger, C. W. J. (1988). Some recent development in a concept of causality. Journal of Econometrics, 39(1-2), 199-211. doi:10.1016/0304-4076(88)90045-0

Hafner, K. A. \& Kampe, L. (2018). Monetary union in Latin America: an assessment in the context of optimum currency area. Applied Economics, 50(52), 5672-5697. doi:10.1080/00036846.2018.1489116

Harvey, S. K. ve Cushing, M. J. (2015). Is West African Monetary Zone (WAMZ) a common currency area? Review of Development Finance, 5(1), 53-63. doi:10.1016/j.rdf.2015.05.001

IMF. (2021). The International Financial Statistics. Erişim adresi https://data.imf.org

Ingram, J. C. (1962). Regional payments mechanisms: The case of Puerto Rico. Chapel Hill, NC: University of North Carolina Press.

Kava, T. H. (2005). ERM II'de gelecek var mı? türkiye açısından olası senaryolar ve politika önerileri nelerdir?. (Yayımlanmamış uzmanlık tezi). Türkiye Cumhuriyet Merkez Bankası, Ankara.

Kazerooni, A. \& Razzaghi, S. (2014). Assessing the Feasibility of Common Currency Area among D-8 Group Members: Structural VAR Model Approach. The International Journal of Applied Economics and Finance, 8(1), 17-28. doi:10.3923/ijaef.2014.17.28

Kenen, P. B. (1969). The Theory of Optimum Currency Areas: An eclectic view (Monetary p., ss. 41-60). University of Chicago Press.

Lee, G. H. Y. \& Azali, M. (2010). The endogeneity of the Optimum Currency Area criteria in East Asia. Economic Modelling, 27(1), 165-170. doi:10.1016/j.econmod.2009.08.004

Lee, G. H. Y. ve Azali, M. (2012). Is East Asia an optimum currency area? Economic Modelling, 29(2), 87-95. doi:10.1016/j.econmod.2011.05.006

McKinnon, R. I. (1963). Optimum Currency Areas. The American Economic Review, 53(4), 717-725.

Meera, A. K. M. (2002). Islamic Gold Dinar. Malezya: Pelanduk Publication.

Mishra, R. K. ve Sharma, C. (2010). Real exchange rate behavior and optimum currency area in East Asia: Evidence from Generalized Purchasing Power Parity. International Review of Financial Analysis, 19(3), $205-213$. doi:10.1016/j.irfa.2010.02.003

Mundell, R. A. (1961). A theory of Optimum Currency Areas. The American Economic Review, 51(4), 657-665.

Nguyen, T. (2010). An analysis of East Asian currency area: Bayesian dynamic factor model approach. International 
Review of Applied Economics, 24(1), 103-117. doi:10.1080/02692170903007631

Numa, M. (2011). The feasibility of a monetary union in MERCOSUR. The Michigan Journal of Business, 4(2), $11-59$.

Rafiq, M. S. (2011). The optimality of a gulf currency union: Commonalities and idiosyncrasies. Economic Modelling, 28(1-2), 728-740. doi:10.1016/j.econmod.2010.05.007

Samsar, A. (2003). Optimal para alanı teorisi çerçevesinde Türkiye analizi. (Yayımlanmamış uzmanlık tezi). Türkiye Cumhuriyet Merkez Bankası, Ankara.

Şimşek, H. (2005). Optimum para sahası teoremi altında Türkiye'nin Avrupa Para Birliğine uyumu. Ekonomik ve Sosyal Araştırmalar Dergisi, 1(1), 53-66.

Tavlas, G. S. (2009). Optimum-Currency-Area paradoxes. Review of International Economics, 17(3), 536-551. doi:10.1111/j.1467-9396.2009.00832.x

The International Monetary Fund. (2020). IMF Direction of Trade Statistics (DOTS). IMF Data. Erişim adresi https://data.imf.org/

Tuğrul, T. (2019). Millî Görüş mefkûresinde İslâm Birliği ve D-8 -teori ve pratik-. Din ve Bilim Dergisi, 2(2), 2349.

Varan, B. (2010). Avrupa Para Birliği, Euro ve Türkiye ekonomisine etkileri. (Yayımlanmamış yüksek lisans tezi). Marmara Üniversitesi Sosyal Bilimler Enstitüsü, İstanbul.

Yılmaz, D. (2014). Para birliği ve finansal kriz yönetimi: AB açısından bir analiz. (Yayımlanmamış doktora tezi). Uludağ Üniversitesi Sosyal Bilimler Enstitüsü, Bursa.

Yücememiş, B. T. (2004). Parasal birlik, Avrupa Merkez Bankası ve Türkiye'ye yansımaları. İstanbul: Derin Yayınları. 
